\title{
PUBLIC OPINION REGARDING THE ROLE OF GOVERNMENT IN REGULATING VIOLENT CONTENT IN VIDEO GAMES
}

by

Helen Wolf

A thesis submitted to the Faculty of the University of Delaware in partial fulfillment of the requirements for the degree of Honors Bachelor of Arts in Communication with Distinction.

Spring 2010

Copyright 2010 Helen Wolf

All Rights Reserved 


\title{
PUBLIC OPINION REGARDING THE ROLE OF GOVERNMENT IN REGULATING VIOLENT CONTENT IN VIDEO GAMES
}

\author{
by
}

Helen Wolf

Approved:

Juliet Dee, Ph.D.

Professor in charge of thesis on behalf of the Advisory Committee

Approved:

Jennifer Lambe, Ph.D.

Committee member from the Department of Communication

Approved:

Danilo Yanich, Ph.D.

Committee member from the Board of Senior Thesis Readers

Approved:

Alan Fox, Ph.D.

Director, University Honors Program 


\section{ACKNOWLEDGMENTS}

There have been many wonderful people who have helped me with this project and I am very grateful for their input throughout the process. First, I would like to thank Dr. Juliet Dee of the Communication Department. Her guidance and support have been vital to the success of my research. I cannot even begin to express how thankful I am for everything she has done for me over the past year.

Next, I would like Dr. Jennifer Lambe for all of her help. Her advice for revisions ensured the validity of many aspects of this project. I would also like to thank Dr. Danilo Yanich for his input and assistance. Both Dr. Lambe and Dr. Yanich were wonderful in providing a fresh look at the many drafts of this paper.

A huge thank you goes to Meg Meiman and the rest of the Undergraduate Research Program for supporting my research since the summer of 2009.

Finally, I need to express my deep gratitude towards Dr. Dick Sacher. His help with the formatting of my survey and the statistical analysis of the results has made this project possible. 


\section{TABLE OF CONTENTS}

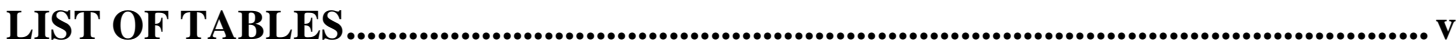

ABSTRACT ................................................................................................................ vii

Chapter

1. Statement of Purpose and Introduction ............................................................... 1

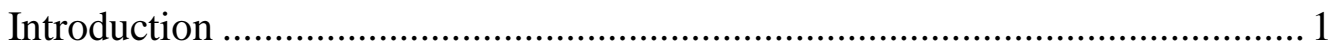

Statement of Purpose, Theoretical Rationale, and Research Questions ............. 2

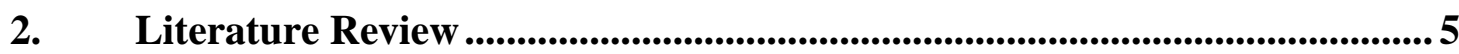

How is Violence Defined? ........................................................................... 5

Psychological Effects of Media Violence.......................................................... 7

Government Restrictions on Violent Content .................................................. 20

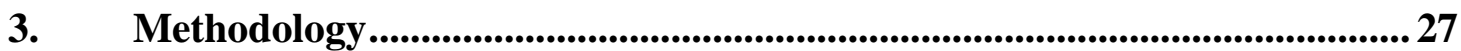

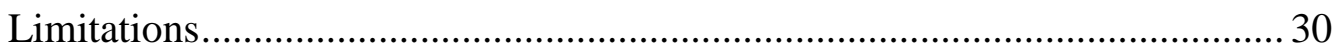

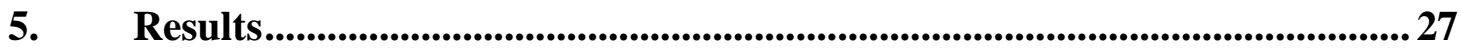

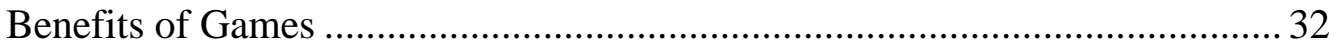

How frequently people play as related to desired levels of restrictions .............35

How responsible are video games for violence in real life? ............................... 38

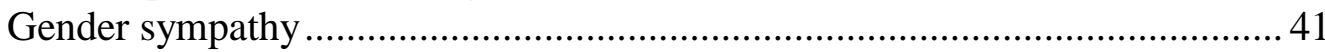

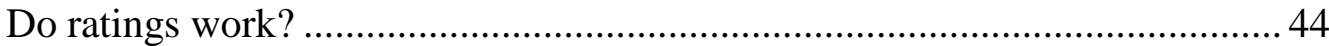

Open Ended Responses ............................................................................ 46

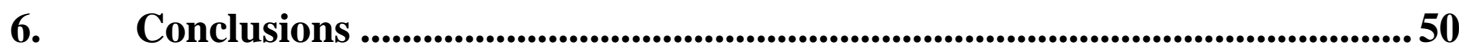

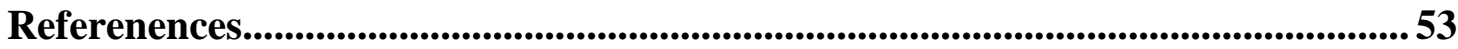

Appendix A.........................................................................................................................56

Appendix B .........................................................................................................................61

Appendix C....................................................................................................................................62 


\section{LIST OF TABLES}

Table 1 Graph of hours per week and reaction time improvement. ......................34

Table 2 Graph of hours per week and reported social network expansion........... 35

Table 3 Hours played per week cross tabulated with whether the ratings system is perceived as necessary. ................................................... 36

Table 4 Graph of hours per week and a perception of government regulation.

Table 5 Evaluation of hours per week and attitudes about whether victims of imitated violence should be able to sue manufacturers for damages.

Table 6 Effects on real life violence cross tabulated with a perception of governmental regulation.

Table 7 Graph of effects on real life violence and whether victims of imitated violence can sue manufacturers.

Table 8 Graph showing gender support for the ratings system. ........................ 42

Table 9 Graph of gender and victim ability to sue. ...................................... 44

Table 10 Age cross tabulated with whether respondents tried to purchase an "M" or "AO" game before 18

Table 11 Content Analysis of Open Ended Responses....................................... 49

Table A1 Hours per week cross-tabulated with reported reaction time. ................. 62

Table A2 Evaluation of hours per week and reaction time improvement. ............. 63

Table A3 Hours per week cross-tabulated with improvement in social network.

Table A4 Evaluation of hours per week and social network expansion. 64 
Table A5 Evaluation of hours played per week and whether the ratings system is perceived as necessary.

Table A6 Hours per week and whether the ratings system is perceived as

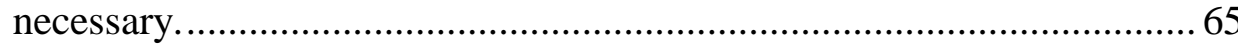

Table A7 Hours per week cross-tabulated with perception of the need for government regulations.

Table A8 Evaluation of hours per week and a perception of government regulation

Table A9 Hours per week cross-tabulated with attitudes about whether victims of imitated violence should be able to sue manufacturers for damages. 66

Table A10 Graph of hours per week playing video games and whether victims of imitated violence should be able to sue manufacturers. 66

Table A11 Evaluation of effects on real life violence and a perception of governmental regulation.

Table A12 Effects on real life violence and a perception of government regulations.

Table A13 Effects on real life violence cross-tabulated with whether victims of imitated violence can sue manufacturers 68

Table A14 Evaluation of effects on real life violence and whether victims of imitated violence can sue manufacturers. 68

Table A15 Gender support cross tabulated with whether ratings are necessary.........68

Table A16 Evaluation of gender support and whether ratings are necessary............69

Table A17 Cross-tabulation of gender and victim ability to sue.................................. 69

Table A18 Chi-square test of gender and victim ability to sue. ................................ 69 


\begin{abstract}
The First Amendment to the Constitution guarantees free speech except in extreme cases. While video games are correctly labeled as "speech," numerous psychological studies suggest that playing these games leads to an increase in addictive and aggressive behaviors. Because of this, experts are divided as to whether or not video games should be legally censored. My research seeks to determine the attitudes of the general public regarding whether legal restrictions on game content are advisable.

This project involves a survey of 350 adult gamers who responded to questions about violent content and video game ratings. Through this survey, I will analyze the attitudes of gamers towards violence in video games and whether or not they believe that the effects of video games can trigger violence in real life. This study will also analyze various options for state and federal legislators to increase the restrictions on retail sales of violent video games to minors through the use of the video game rating system. Finally, I conclude that it is not the government's role to restrict the access of minors to video games. It is the parents' job to monitor their children's gaming habits.
\end{abstract}




\section{Chapter 1}

\section{STATEMENT OF PURPOSE AND INTRODUCTION}

\section{$\underline{\text { Introduction }}$}

Video games are one of the most popular forms of entertainment produced in the United States and throughout the world. When Call of Duty: Modern Warfare 2, was released in late 2009, it broke standing records for entertainment releases, beating some of the most popular movies and music releases in recent years (PR Newswire 2009). Children and teens enjoy the advanced interactive technology in the comfort of their homes, or in the homes of their friends. Even adults find pleasure in video games. As an industry, video games are available to and find favor with every age group and every socioeconomic group as well.

Not all video games are considered appropriate, however. Along with their popularity come concerns about the graphic nature of the sex and violence portrayed in certain video games. As a result, lawmakers argue over the level of control they feel they should have over the video game industry. Many believe that video games have become too grotesquely violent and so they push for censorship. Others say that the First Amendment prohibits interference in the industry in any capacity. The results of this debate are present in lawmaking arenas and in courtrooms. Almost all attempted legislative restrictions have failed, and precedent tells judges that video game manufacturers have the right to create whatever they like. 
On the other hand, psychological research shows that playing violent video games has negative effects on children's cognitive functioning. As research continues to emerge that supports this conclusion, certain lawmakers and citizens' action groups push for censorship.

\section{Statement of Purpose, Theoretical Rationale, and Research Questions}

In first grade, I was a member of a four-kid gang that went around imitating TV westerns. We'd disrupt class to play out scenes, picking up chairs and hitting people over the head with them-except, unlike on TV, the chairs didn't break, the kids did. Finally, the teacher called my parents in and said 'Obviously he's being influenced by these shows, and if he's to continue in this class, you've got to agree not to let him watch television anymore.' So from the first to second grade there was a dark period during which I didn't watch TV at all. And I calmed down and the game broke up. -Brandon Tartikoff, former president of the National Broadcasting Company (cited in Grossman and Degaetano 1999, p. 23).

The freedom of speech established by the First Amendment to the Constitution is considered a basic tenet of the American political system. The Amendment asserts that "Congress shall make no law respecting an establishment of religion, or prohibiting the free exercise thereof; or abridging the freedom of speech, or of the press; or the right of the people peaceably to assemble, and to petition the Government for a redress of grievances." While the Founding Fathers felt strongly about establishing this right to free speech, modern controversies demonstrate the ambiguity of the Amendment's reach. Political scientists "have recognized that the commitment of the public to protecting free expression is essential to maintaining... freedoms" (Lambe 2002, p. 187). To protect these basic freedoms, judicial decisions typically uphold the rights of expression. According to Dr. Jennifer Lambe, "the actions of state and federal legislators, as elected representatives, are intended to be 
responsive to public opinion. And, in several areas of First Amendment law, judges and juries are required to base their decisions on an understanding of public attitudes" (2002, p. 188). It is essential, therefore, to ascertain an accurate reflection of public opinion so that courts and legislators can make decisions accordingly.

The purpose of this research, therefore, is to examine the general public's attitudes toward the roles that the legislative and judicial branches of government play in relation to the video game industry. By polling a sample population, I am seeking to determine attitudes among the general public regarding the extent to which the government should regulate violent content in video games, if at all. Through an online survey, people were asked a series of questions so that the following research questions could be answered:

1. Does the general public perceive that video games instigate copycat violence in real life?

2. Does the general public feel that legislation should be enacted that will restrict the violence in video games?

3. Does the general public think that the rating system for video games is a sufficient level of regulation?

4. Does the general public believe that victims of copycat violence should prevail in lawsuits against video game manufacturers?

I asked a sample of 345 people their opinions on these questions. By asking people who are not directly involved in politics or the video game industry, I thought that I might be able to find opinions that would be representative of the general population.

Before creating the survey, I hypothesized that the results of the survey would reflect sympathy for victims of copycat violence. I thought that in general, those 
people who believed that video game violence caused violence in real life would agree that government censorship and judicial sanctions would be acceptable and necessary. I also believed that women would be more likely to agree with censorship than men. The hypotheses for this research project were as follows:

H1: The more frequently people play video games, the more sympathetic they will be with video game manufacturers.

$\mathrm{H}$ 2: People who believe that video game violence instigates violence in real life will also believe that government censorship is necessary.

H3: People who believe that video game violence instigates violence in real life will also believe that victims of copycat violence should be able to successfully sue video game manufacturers for damages.

H4: Women will be more sympathetic toward victims of copycat violence than will men. 


\section{Chapter 2}

\section{LITERATURE REVIEW}

The study of media violence and its effects on viewers is extensive, but complicated. One of the most prevalent obstacles to this type of research is defining the term "violence." Different studies use varying definitions of violence. On the other

hand, even with differing views of what violence is, the findings regarding psychological research on effects of violent content consistently point to the fact that exposure to violent content in the media can increase aggressive behavior in real life. Applying these results, lawmakers must analyze what actions would be in the best interests of consumers. They must decide whether manufacturers' First Amendment rights should be protected or whether violent content can be restricted if it is judged as being "harmful to minors."

\section{How is Violence Defined?}

In May of 1972, Magnavox released the Odyssey, a gaming system on which games like Pong could be played. As games became increasingly complex, manufacturers sought new ways to draw in consumers. Television and movie producers were beginning to use violence to drive their story lines and rarely showed consequences for violent actions. This focus on violence was wildly successful. Video game makers quickly picked up on this trend and applied the "violence formula" to the games that they produced. As a result, the video games on the market today are often grotesquely violent and excessively pornographic. 
In the book Stop Teaching our Kids to Kill, David Grossman and Gloria Degaetano (1999) explained that between 1960 and 1991, the population in the United States increased by 40 percent. In that same time period, the reported violent crime rate increased by a rate of 500 percent:

Murders increased by 170 percent, rapes 520 percent, and aggravated assaults 600 percent. The violence in the mass media has been blamed for a large part of this massive increase in violence. Children, in particular, are affected by contact with violence. They learn how to hurt each other in new ways and that violence is the preferred method of settling disputes through this media exposure (Grossman and Degaetano 1999, p. 11-19).

In the decade since Grossman and Degaetano published their book, the amount of graphic violence in video games has continued to increase.

The popular series Grand Theft Auto, for example, is noted for content that is inappropriate for minors. Legal scholar Timothy Dylan Reeves describes Grand Theft Auto as providing a way for people to "live out their sociopathic fantasies through random acts of senseless violence" (Reeves 2009, p. 522). In addition, on November 11, 2009, Call of Duty: Modern Warfare 2 was released and set world records for sales. Even though it is rated "M," and therefore legally available to a limited consumer audience, Robert Kotick, CEO of Activision Blizzard, Inc. reported to a news source that "In just five days...Call of Duty: Modern Warfare 2 has become the largest entertainment launch in history and [a] pop culture phenomenon" (PR Newswire 2009). In that same article, it is reported that the game grossed an estimated \$550 million in five days (2009). Clearly, violence sells video games.

On the other hand, video game manufacturers insist that their games have not had any impact on the violent crime rate. If anything, they argue, that violent crime has decreased since the release of modern gaming systems. The Bureau of Justice 
Statistics supports this claim and it states on its website that violent crime rates have decreased since 1993. "Serious violent crime," according to the site, consists of rape, robbery, aggravated assault and homicide. In 1990, the National Crime Victimization Survey reported that there were 3,499,700 cases of violent crime in the United States. By 2000, that number had decreased to 2,186,300 estimated cases. In 2007, the estimate had reached 1,613,100 cases of violent crime (Bureau of Justice Statistics 2010). This discrepancy between the Bureau of Justice and Statistics and political activists suggests the importance of establishing a consistent definition for violence. The violence acts included in the reports of the opposing groups are defined in different ways. By including or excluding certain acts of violence in the general category of "violent acts," it becomes possible to make the statistics fit the source's

needs. Violent behavior, for the sake of this research, will be defined as any aggressive actions that involve the intent to cause harm.

\section{Psychological Effects of Media Violence}

There has been extensive research on the cognitive effects that viewing media violence has on children. Most of this research supports the theory that viewing violence has negative and lasting effects on children. According to Time Magazine, for example, approximately eight percent of American children showed "pathological" habits when playing video games (Altman et al. 2009, p. 15). Pathology, in this sense, means addictive behaviors such as skipping meals or school to play games instead.

Ironically, video games also have positive effects on players. For example, many educational video games "allow our students to face complex challenges and problem solve while [they] question the world in which they are immersed, constantly observe their virtual world, and quickly interact with highly adaptive creatures..." 
(MacKenzie 2005, p. 518). On the other hand, most of the games that children play are not of the educational variety. Children and adolescents prefer violent video games to all other genres (Garabino et al. 2002, p. 78). Educational games are effective because they force players to find creative solutions to problems. Violent video games also require problem-solving but in a very different way. Because of the active role that players have, "It helps educational video games be excellent teaching tools for motivational and learning process reasons. But, it also may make violent video games even more hazardous than violent television or cinema" (Anderson 2003, apa.org).Therefore, while video games can have positive effects on players, there are equally prevalent negative effects when the games that are most prominently played contain violent content.

Scientifically, there has been extensive research about the growth of the brain during adolescence. The effects that video games have on young players can be the result of natural biological development. Adolescence, according to psychologists, is a wide range of time and is not limited to what is traditionally called the "teenage" years. Ronald E. Dahl, a professor of psychiatry and pediatrics at the University of Pittsburg Medical Center, defines adolescence as the “... awkward period between sexual maturation and the attainment of adult roles and responsibilities" (Dahl 2004, p. 9). This period of pubertal maturation is identified by "the development of cognitive, emotional, and social skills and knowledge, as well as the maturation of judgment" (Dahl 2004, p. 11). Dahl says that for many people, this stage of development begins between 9 and 12 years of age and can last anywhere from 8-15 years, or possibly more (Dahl 2004, p. 14). Adolescence is not just a time of sexual and social maturation, but is also a major time for cognitive growth. 
The types of growth that occur during adolescence have the potential to cause psychological issues. Dahl explains that the way the brain grows creates a “potential for dys-synchrony” (2004, p. 16). This leads to adolescents commonly seeking sensation-based experiences: "Part of the vulnerability...in this period of development may be linked to a set of biologically based changes in neural systems of emotion and motivation, which contribute to... a natural increase in tendencies toward risk taking, sensation seeking, and some emotional/motivational changes during pubertal maturation" (Dahl 2004, p. 7). There have been numerous recent developments in neurological research that depict the physical change in the brain over the course of adolescence:

Over a span of roughly... twelve years, the adolescent brain...is transformed from child to adult. The gray matter of an adolescent's frontal lobes grows denser and then abruptly scales back, molding a leaner thinking machine. The teenage brain fine-tunes its most human part, the prefrontal cortex, the place that helps us cast a wary eye, link cause to effect, decide "maybe not" - the part, in fact, that acts grown up (Saunders 2005, p. 710).

The physical changes that occur in the brain throughout growth have been well documented in recent years. In addition to physical changes in the brain, this time is also marked by maturational improvements in many areas, including cognitive reasoning and the ability to withstand physical stress. On the other hand, it is also the time when "morbidity and mortality rates increase 200\%..." (Dahl 2004, p. 3). The tendency for adolescents to seek intense experiences due to psychological dyssynchrony can result in accidents, suicide, homicide, depression, alcohol and substance abuse, and health problems related to risky behaviors that lead to the deaths of many teenagers. 
Clearly, neurological growth has major effects on the activity of adolescents. For some, the drive towards strong emotions and "an affinity for excitement can be subtle and easily managed. In others, these inclinations toward highintensity feelings can lead to impulsive decisions by (seemingly) intelligent youth that are completely outrageous" (Dahl 2004, p. 8). Under situations of intense emotional arousal, intelligent youths are more likely to make bad decisions. One of the main functions of the brain is to inhibit negative behaviors. While the brain is still growing, this function has the potential to be stalled. In fact, "it is this very inhibition machinery that is being fine-tuned" (Saunders 2005, p. 712). In addition, it is shown that youthful memories cause a physical change in brains. This means that whether a child is learning in a classroom or "shooting a character in a video game," the actions of children become clearly embedded in their physical memories (Saunders 2005, p. 711). Playing video games during the period of brain development can imprint the memories of those actions into the brain so that those actions can be recalled easily. Playing video games, then, becomes a type of practice. The actions portrayed on the screen are imprinted in memory so that they are easily recalled and transferred into the real world.

The issue over video game effects on cognition has attracted the attention of lawmakers. On July 26, 2000, there was a Congressional Public Health Summit. The medical community joined with federal agencies to summarize the findings of research conducted on the topic. They released a statement that said:

At this time, well over 1000 studies_-including reports from the Surgeon General's office, the National Institute of Mental Health, and numerous studies conducted by leading figures within our medical and public health organizations - our own members - point overwhelmingly to a causal connection between media violence and 
aggressive behavior in some children. The conclusion of the public health community, based on over 30 years of research, is that viewing entertainment violence can lead to increases in aggressive attitudes, values, and behavior, particularly in children (American Academy of Pediatrics 2000).

The findings show that there is not only a strong correlation between viewing violence and increased aggression in children, but there is a causation factor. Much of the research conducted before this summit had led to these results and the research done afterwards largely points to support for these conclusions.

Neurological research shows a clear physical change in the brain that can lead to increased effects of viewing media violence. In addition to these scientific studies, social science also supports these claims. Many of the studies cited by the medical authorities at the Congressional Summit have been longitudinal social scientific experiments in order to establish the long-lasting effects of video game violence. In 1987, Eric F. Dubow, L. Rowell Huesmann and Leonard D. Eron published the results of a study that had begun when the subjects were 8 years old and ended when the subjects were in their 30s. They showed that "childhood and adolescent indicators of impulse control and cognitive development (nonaggression, prosocial behavior, and intelligence) were associated with higher levels of adult ego development" (Dubow, Huesmann, and Eron 1987, p. 859). Their studies found that the ways in which children were raised and the types of punishments and rewards to which children were exposed had a lasting effect on behavior. Critic Susan Hurley commented that their study showed that "viewing media violence by 8 -year-old boys is strongly correlated with aggressive behavior by those same boys 10 years later" (2004, p.180). Therefore, those boys that had the greatest preferences for media violence 
while young were the same boys who were most likely to have been convicted of a serious crime by the time they were 30 .

Dubow et al. showed that in addition to media exposure, parental styles and peer interaction were strong indicators of ego development in [the] subjects (1987, p. 859). Hurley observed that similar studies have shown similar results in five different nations (2004, p. 180). These longitudinal studies have shown that children exposed to and drawn to media violence at a young age are more likely to be aggressive later in life.

This can be partially explained by the fact that the more children view violence, the more natural it becomes to them. Grossman and Degaetano explain: Children are bombarded with thousands of violent acts on television at a young, vulnerable age when they literally cannot tell the difference between reality and fantasy. As violence is played for laughs and cheers on TV and in the movies, our kids eat their favorite snacks and giggle as the body count rises (Grossman and Degaetano 1999, p. 3).

This type of exposure leads to desensitization toward violence in real life and creates the perception that the world is a violent place and so it is necessary to use violence to solve conflicts.

In addition to desensitization, another potential explanation for the causal connection between playing aggressive video games and increased violent behavior in real life is cognitive priming theory. Richard Felson explains cognitive priming: "The aggressive ideas in violent films can activate other aggressive thoughts in viewers through their association in memory pathways. When one thought is activated, other thoughts that are strongly connected are also activated" (Felson 1996, p. 112). Similar theories include full-fledged imitation, emulation, response priming, and stimulus enhancement (Hurley 2004, p.167). All of these theories suggest that viewing certain 
actions creates a specific, trained response in the viewer. Taken together, these theories help support the conclusion reached by the medical community that there is a causal link between playing aggressive games and then acting them out in real life.

One of the major premises of priming research is that exposure to media violence by itself is not enough to cause significant cognitive violent responses. While it is a factor, other variables also contribute to aggression. The Congressional Summit Report explained that "Family breakdown, peer influences, the availability of weapons, and numerous other factors may all contribute to these problems" (2000). In addition, divorce, child abuse, exposure to alcohol and tobacco, and traumatic childhood experiences can be contributing factors that will magnify the effects of viewing media violence.

Another concern about video games focuses on online gaming communities. Online, people are able to create avatars and act out their fantasies without fear of reprimand. Some forms of online gaming allow voice communication which results in social networking. Because of the social connections that are allowed through online gaming communities, research suggests that some people blur the lines between fiction and reality. For example, "The new fear is that individuals will be so enabled in their ability to customize connectedness that they will fashion an experience that exposes them to only like-minded people and ideas" (Williams et al. 2007, p. 431). People create their own realities online and construct their own worlds in which diversity is non-existent or rare.

Despite all of this existing psychological and sociological research, there are many critics who completely deny that viewing media violence has any negative effect on children. Some feel that the blame placed upon the entertainment industry is 
exaggerated or misplaced. Many of these people look to the history of entertainment violence and emphasize that most of these historical media had no effect. For example, John Leonard draws a parallel and claims that “...either the Old Testament or the Iliad was the first Western" (Leonard 1993, p. 36). Leonard further explains that: "each year 2 million American women are assaulted by their male partners, who are usually in an alcoholic rage, and whose fault is that? Miami Vice? The gangs that menace our streets aren’t home watching Cinemax...” (Leonard 1993, p. 36). Leonard is not alone. Critics often point to history to show that the current controversies are exaggerated. Singer and Singer describe that "the first dolls and occasionally warlike sets are traceable to ancient Egypt...The simulation of warfare in games is thus as old a tradition as one can find in the history of play" (Singer and Singer 2005, p. 85). Many people feel that the psychological effects claimed by psychologists and lawmakers are exaggerated.

\section{$\underline{\text { Legal Battles over Copycat Violence }}$}

Because the medical community agrees that viewing violence can lead to aggressive acts in children, the issue becomes one of responsibility. Who should be held responsible for acts of violence that are committed by minors as a response to violence they have seen? Copycat violence is a phenomenon that occurs when someone imitates an act of violence that he or she has seen on television or enacted through a video game. In recent years, there have been several cases of copycat violence as the result of playing violent video games.

In 1997, 14-year-old Michael Carneal brought four guns to his high school and opened fire on a prayer group. He killed three young women and injured five more students. Grossman and Degaetano explain that he fired eight rounds into the group of 
people. All eight shots hit someone. They explain that he was able to do this because of the practice he had from video games: "At the tender age of fourteen he had practiced killing literally thousands of people. His simulators were point-and-shoot video games he played for hundreds of hours in video arcades and in the comfort of his own home" (1999, p. 4). The parents of the three young women that Carneal murdered were the plaintiffs in James v. Meow Media (1998). They claimed that the defendants "manufactured or supplied Carneal [with] violent video games which made the violence pleasurable and attractive, and disconnected the violence from the natural consequences thereof..." (Li 2003, p. 470). The families of the victims also blamed pornographic websites and the movie Basketball Diaries for Carneal's act of violence. In January of 2004, the United States Supreme Court "upheld a federal appellate court decision dismissing a lawsuit against [the plaintiffs in James]" (Calvert and Richards 2004 , p. 203). The case was thus dismissed and the victims of the shooting were not permitted to continue with their case.

Even worse, on April 20, 1999, Eric Harris and Dylan Klebold “massacred twelve students and a teacher, injured twenty-three other people, and committed suicide at Columbine High School" (Li 2003, p. 468). Two years after the shooting, relatives of the victims filed suit against 22 entertainment companies, including several of the companies named in James. In this case, Sanders v. Acclaim Entertainment Inc., "the plaintiffs alleged that the defendants' video games made violence pleasurable and attractive to Harris and Klebold, disconnected the violence from its natural consequences, and trained them to point and shoot a gun" (Li 2003, p. 471). In James and Sanders, the plaintiffs were unsuccessful because their suits were barred by the First Amendment. 
Four years after the Columbine High School massacre, on June 72003 , police brought Devin Moore into an Alabama police station on suspicion of car theft. Newscaster Ed Bradley gave this account:

...Moore snapped. According to Moore's own statement, he lunged at Officer Arnold Strickland, grabbing his .40 caliber Glock and shot Strickland twice... After he shot Strickland, Moore turned the weapon on Officer James Crump. Moore then continued down the hallway of the police station [and] fired at dispatcher Ace Mealer. He took a set of car keys and "took off" in a police cruiser. It all took less than a minute, and three men were dead (Bradley 2005, cbsnews.com).

Moore's behavior was linked to the video game Grand Theft Auto. Many critics of the violent outburst compared Moore's actions to the violence against police officers present in the game. A law suit was thus filed against the makers and manufacturers of the violent video game. In Bradley's newscast, attorney Jack Thompson claimed "that Devin Moore was, in effect, trained to do what he did. He was given a murder simulator" (Bradley 2005, cbsnews.com). After the police recaptured Moore, he even said to police that "Life is like a video game. Everybody's got to die sometime" (Bradley 2005, cbsnews.com).

While psychological studies have proven that video games can have an aggressive priming effect on gamers, the courts have upheld the First Amendment rights of video game manufacturers on the grounds that First Amendment rights overrule the plaintiffs' claims of negligence. Before video games could be protected under the First Amendment, they had to be considered "speech" under the legal definition. Legal battles over the earliest versions of video games led to the conclusion that video games did not constitute speech because they "contain so little in the way of [a] particularized form of expression" (Li 2003, p. 473). It was not until 2001 in the case of American Amusement Machine Association v. Kendrick that the courts legally 
recognized video games as a form of expression and, therefore, as speech. U.S. Court of Appeals Judge Richard Posner explained: "The grounds [for censorship of video games] must be compelling and not merely plausible. Children have First Amendment rights" (American Amusement Machine Association v. Kendrick, 2000). Plaintiffs, therefore, must show that children are directly harmed by the content in a video game before a court will regulate the content in that game. The first step in these cases, then, is to establish a causal relationship between the individual playing a specific violent video game and his or her subsequent violent recreation of what was seen in that video game.

Another potential judicial path is through exceptions to First Amendment protection for speech. In order to win a lawsuit against video game manufacturers, plaintiffs would have to prove that the content of a game constitutes a form of speech that is not protected. There are certain categories of speech that the First Amendment does not protect, such as fighting words, obscenity, and incitement. Most of the arguments used against the entertainment software industry claim that certain video games contain obscenity or else they incite players to commit violence in real life.

Legally, obscenity is difficult to define. The court established a test for determining what constitutes obscenity, however, in the case of Miller v. California (1973). The test says that a work is obscene if:

(a) the average person, applying contemporary community standards would find that the work, taken as a whole, appeals to the prurient interest; (b) whether the work describes "in a patently offensive way, sexual conduct specifically defined by the applicable [state] law; and (c) whether the work, taken as a whole, lacks serious literary, artistic, political, or scientific value. (Miller v. California, 1973). 
The courts have so far rejected most arguments that claim that certain video games are obscene. Judges do not find that the portrayal of sex in most video games constitutes obscenity according to the Miller $v$. California test. Judicial precedent dictates that the Miller obscenity test is only applicable to scenes of sex; it cannot be applied to violence. Some critics claim that the test should be changed so that the phrase "appeals to the prurient interest" could include "or morbid interest" (Li 2003, p. 479). Because of the limited definition of obscenity, as it currently stands, plaintiffs are unlikely to be able to argue a case against video game manufacturers using an obscenity argument.

The other popular argument against video game violence is that it constitutes "incitement to commit imminent unlawful activity." The First Amendment protects abstract notions of violence but not speech that is "directed to inciting or producing imminent lawless action and is likely to incite or produce such action" (Brandenburg v. Ohio, 1969). In Brandenburg, the U.S. Supreme Court added the additional requirement of "intent" to incite violent action and the requirement that violence must be imminent. No court has ever held that video games constitute legal incitement. In both James and Sanders the courts held that the manufacturers "obviously did not intend to cause their consumers to commit violent crimes" (Li 2003, p. 483). Justice John Marshall Harlan explained that one of the major issues with the incitement claim is that not everyone commits violent acts after viewing or playing violent content. He said: "The First Amendment does not hold those whose ideas inspired the crimes to answer for such acts. To do so would be to allow the freaks and misfits of society to declare what the rest of the country can and cannot read, watch and hear" (James v. Meow Media, Inc., 2002). Courts are unwilling, 
therefore, to accept arguments such as incitement when only a few individuals are affected by violent content.

According to legal scholar Timothy Reeves, however, video game manufacturers should be held liable for instances of copycat violence under the tort of negligent entrustment. Reeves explains:

Under a theory of negligent entrustment, the plaintiff would assert that the manufacturer had knowledge that consumers of their violent video games were susceptible to increased aggression or to commit violent acts... Privy to the knowledge that consumers who play the game can present dangerous characteristics, the manufacturers have a duty to take proper precautions to prevent real-life violence. A manufacturer breaches that duty when a player commits a real-life act of violence that is attributable to the video game (2009, p. 536).

The tort of negligent entrustment is separate from other theories of negligence. In this case, "the duty arises... only where a reasonable person would recognize the existence of an unreasonable risk of harm to others..." (Reeves 2009, p. 537). Because there is an abundance of psychological research available that suggests that violent video games present a risk to minors, Reeves argues that video game manufacturers have a duty to interfere and remove the prevailing risk (2009, p. 536). This has not yet been a successful argument.

A common theme in litigation against video game manufacturers has been that there is not yet sufficient research that proves causation between viewing media violence and increased aggression. While Capital Hill supports the medical community in their assertions of causation, the courts demand more direct proof than what has been demonstrated by social science. In order to successfully prove causation, "future research...must involve minors (not college students or adults), must involve the specific games that are regulated (not violent games generally), must prove actual 
causation (not merely correlation) of violent conduct (not merely attitude change or aggressive tendencies)" (Calvert and Richards 2004, p. 222-223). Conducting this type of research on a case-by-case basis is highly unlikely. Furthermore, causality will be "difficult to establish because of many intervening and extraneous variables are involved" (Calvert and Richards 2005, p. 103). To conduct these specific research projects would be extremely expensive and extensive.

\section{Government Restrictions on Violent Content}

Although the judicial system follows precedent and avoids infringement on the First Amendment rights of the entertainment industry, the legislative branch of government is more active in seeking ways to censor game content. Few attempts at restrictions have been successful, however. In 1994, the Entertainment Software Ratings Board (ESRB) was established with the intention of rating all video games according to their content. Since then, the ESRB has continued to rate video games. On May 7, 2008, a bill was introduced to the House of Representatives that would require a "ratings label on video games and to prohibit the sales and rentals of adultrated video games to minors" (Matheson 2008, p. 1). Video games are now legally required to include ratings on all gaming systems. So far, the only legislation Congress has passed is the requirement that video game manufacturers provide ratings and descriptive explanations for each game released.

The ratings system consists of six categories ranging from "Early Childhood" to "Adults Only." Games that are rated "M" for "mature" are considered

appropriate for those ages 17 and older and "AO," for "adults only," are only suitable for people 18 and older (esrb.org 2009). However, "Studies show that pre-teen and adolescent boys favor violent video games with the ' $\mathrm{M}$ ' rating... and that minors have 
no trouble purchasing these games despite self-imposed industry regulations" (Reeves 2009, p. 520). While the ratings system exists, and manufacturers follow ESRB guidelines, gaming vendors are not adequately regulated. Minors can get access to games with relative ease. Because of this, some legislators are pushing for further regulations and possibly for censorship. The courts have overturned many legislative efforts to regulate video game distribution. Legislators have attempted to limit advertising, to require retailers to display " $\mathrm{M}$ " and "AO" games separately from other games, and to prohibit access to violent video games in prisons. Of these endeavors, only one jurisdiction requires retailers to display violent video games separately from other games (medialegislation.org 2006). The other attempted regulations have failed in all jurisdictions.

The Congressional Summit of 2000 spurred many lawmakers into action but they are having difficulty seeing results. The video game industry regulates itself to an extent by including ratings on all of their released games and prohibiting retailers from selling "M" and "AO" games to minors. These are the only federal regulations in place thus far.

In order to have successful legislation passed and not be struck down by the Supreme Court, the regulation at issue would have to be specific and limited. Judge Robert Lansik wrote in his decision of Video Software Dealers Association $v$. Maleng that he is not a fan of violent video games, but that precedent and the law dictate that restrictions on video game content are unlikely to pass. He says that in order for a restriction to pass, there are three aspects to the regulation that must be present. First, he claims that the regulation must cover "only the type of depraved or extreme acts of violence that violate community norms and prompted the legislature to 
act" (VSDA v. Maleng, 2004). The issue with this first consideration is the ambiguous language. The use of the phrase "extreme," for example, suggests a level of degree that the courts must review.

The second consideration that Lansik outlined is that the regulation must prohibit "depictions of extreme violence against all victims, regardless of their viewpoint or status" (VSDA v. Maleng, 2004). This consideration is meant to follow a content-neutral censorship regime. By not discriminating based on viewpoint, the court is attempting to ensure the protection of manufacturers' First Amendment rights. The final consideration, according to Lansik, is that the regulation rely on "social scientific studies [that] support the legislative findings at issue" (VSDA v. Maleng, 2004). The kinds of studies that would be accepted by the court would need to be very specific and realistic. These points that Lansik outlines are complicated and regulations are unlikely to fit into these points perfectly. Because of their ambiguity and subjectivity, regulations are still unlikely to pass.

Many opponents of video game regulations claim that self-regulation by the video game manufactures is the ideal solution to restricting access to violent content. The ratings system began as a self-imposed policy in the 1990s. The Federal Trade Commission wishes to determine the effectiveness of the ratings system each year so they regularly conduct surveys involving undercover shoppers. The shop conducted between October 2005 and January 2006 "involved 406 stores in 43 states... [306] of the stores were national retailers, while the other 100 were local and regional sellers" (FTC 2006). In this shop, it was revealed that only 42 percent of secret shoppers, who were between the ages of 13 and 16, were able to purchase a video game with an " $\mathrm{M}$ " rating. This is a marked decrease from the 69 percent who 
were able to purchase an "M" game in 2003. Each year that the FTC has conducted this secret shop, the percentage of minors who were able to successfully purchase a game rated " $\mathrm{M}$ " has decreased and the percentage of cashiers who ask for the child's age has increased.

In addition to these secret shops, the FTC also looks at marketing plans of video game manufacturers to determine the target audience of the advertising. These investigations look to determine whether: "[entertainment industries] promote products that they themselves acknowledge warrant parental caution in venues where children make up a substantial percentage of the audience and whether their advertisements are intended to attract children and teenagers" (FTC 2001, p. 1). When the FTC first conducted this survey in 2000, they found that the music, movie, and gaming industries were all guilty of both. As a result, the industries were given several recommendations that were meant to decrease marketing to minors. The video game industry established a self-regulatory code before this survey was conducted that prohibited widespread marketing of mature content to children under 17 years of age. Specifically, it "set limits on the percentage of the audience under 17 that could be viewing, listening, or watching ads for M-rated games on TV and radio (35\%), print (45\%), and the Internet (45\%)" (FTC 2001, p. 23). For the most part, this selfregulatory system has been effective and according to the survey by the FTC, most manufacturers follow these restrictions.

The larger issue, besides manufacturers themselves, is that retailers are less likely to promote the ratings and content descriptors that are assigned to video games. Unfortunately, retailers "are not subject to the same self-regulatory requirements as game publishers, [but] they have been encouraged to follow the ESRB 
rating system" (FTC 2001, p. 30). Because of this, the FTC included a study of retail establishments and their practices. They found that "with the exception of Chips \& Bits and Amazon.com, each of the retailers displayed the rating icon, usually on the clip art showing the games' package cover" (FTC 2001, p. 30). The mystery shop conducted in 2005 and 2006 shows that more retailers are paying attention to the ratings system and the ESRB suggestions. When looking at online retailers, the Commission found that "of the 21 games that could be purchased online, 15 could be purchased only by credit card... In addition, three of the sites that sold games expressly prohibited the sale of M-rated games to children under 17" (FTC 2001, p. 33). To restrict access to violent video games, online vendors typically require a credit card for purchase. By requiring a credit card, retailers necessitate parental consent.

Legislators seem to feel that the FTC's findings about retailers and marketing plans are steadily improving, but are still insufficient to protect minors. As a result, they try to pass laws to restrict access to violent video games but these have all been unsuccessful. This fall, the Supreme Court will begin to hear arguments in the case of the most recent attempt at video game regulation. The Court will have the opportunity to determine the appropriateness of a law passed in California that requires retailers to enforce the ratings system. In late 2005 Governor Arnold Schwarzenegger signed a law that says "[a] person may not sell or rent a video game that has been labeled as a violent video game to a minor... Violaters are subject to a civil penalty of up to \$1,000" (Video Software Dealers Association v. Schwarzenegger, 2009). In this act, violent video games are defined as:

...a video game in which the range of options available to a player includes killing, maiming, dismembering, or sexually assaulting an image of a human being, if those acts are depicted in the game in a manner that does either of the following: ... (i) A reasonable person, 
considering the game as a whole, would find that it appeals to a deviant or morbid interest of minors. (ii) It is patently offensive to prevailing standards in the community as to what is suitable for minors. (iii) It causes the game, as a whole, to lack serious literary, artistic, political, or scientific value for minors. (B) Enables the player to virtually inflict serious injury upon images of human beings or characters with substantially human characteristics in a manner which is especially heinous, cruel, or depraved in that it involves torture or serious physical abuse to the victim (Video Software Dealers Association $v$.

Schwarzenegger, 2009).

This description of violent content in video games closely mimics what is outlined as being offensive under the Miller $v$. California test for obscenity but in a violent context. While this attempt to squeeze violent content into the obscenity test has never been successful in the past, the Supreme Court will have the opportunity to decide if today's standards in entertainment require this addition.

Legal scholars had predicted that this application of the obscenity test would not meet legal requirements. The federal district court and Court of Appeals in California both struck down the law as being unconstitutional. The Court of Appeals for the Ninth Circuit held that under a strict scrutiny standard of review,

the Act violates rights protected by the First Amendment because the State has not demonstrated a compelling interest, has not tailored the restriction to its alleged compelling interest, and there exist lessrestrictive means that would further the State's expressed interests. Additionally, we hold that the Act's labeling requirement is unconstitutionally compelled speech under the First Amendment because it does not require the disclosure of purely factual information; but compels the carrying of the State's controversial opinion (Video Software Dealers Association v. Schwartzenegger, 2009).

The courts held that the act was not constitutional under the requirements of the First and Fourteenth Amendments. In April of 2010, the Supreme Court agreed to review the decision by the Ninth Circuit Court of Appeals (Holland 2010). Opponents of the legislation argue that the Court of Appeals was correct in their decision because of the 
existing efforts by the ESRB: "video games already are labeled with a rating system that lets parents decide what games their children can purchase and play" (Holland 2010). The U.S. Supreme Court will hear oral arguments in the fall of 2010 and that decision will have a large impact on future legislative efforts by state and federal assemblies.

Unless the Supreme Court finds in favor of the California law, future government regulation is unlikely. There have been many attempts at restricting the types of violent content in video games or the ways in which violent games can be sold. Of all of these attempts, very few have withstood judicial review. To date, only the ratings system has been universally accepted. Instead of government interference, an increase in self-regulation by the video game industry is more likely to effectively restrict minors' access to inappropriate material. 


\section{Chapter 3}

\section{METHODOLOGY}

To test my hypotheses, I created an online survey through Qualtrics Survey Software. I then used the social networking website Facebook to distribute the survey. To do this, I created a group and invited all of my "Facebook friends" to join. Within the group was a link for the survey. I asked specific individuals in Virginia, Colorado, California, and New York to distribute the survey. I hoped that by doing this, I would have a wider set of responses from across the country. I also asked several professors at the University of Delaware to distribute the survey to students in their classes. 411 people began the survey but only 345 completed it. Only those surveys that were completed were counted in the analysis $(\mathrm{N}=345)$.

The survey was available from July 15, 2009 through December 18, 2009. There were three sections to the survey: questions about video game play, perceptions of video game violence and how it relates to real life, and demographic data. For a list of the questions, see Appendix A.

\section{Video Game Play}

The survey began with basic self-report questions about the respondent's level of video game play. The first question asked whether the respondent had played video games in the past five years. Respondents could either respond "yes" or "no." If the respondent did play video games, then he or she was directed to a set of questions that were specific to gaming behaviors. 
For those that have played video games, they were then asked to approximate how many hours per week they play. Respondents could answer "0-1," “2-5," "6-10," “11-15," “16-20,” or " $21+.$, Following this question, I asked respondents to estimate the level of improvement that has occurred as a result of playing video games. The questions in this section asked respondents how much their reaction time had improved and how their social network had expanded as a result of playing video games. For these questions, respondents were asked to rate their improvement on a scale that included "not at all," "a small amount," "a moderate amount," and "a great deal."

I then asked respondents to estimate their knowledge about the ratings of the video games that they own. Specifically, I asked respondents to think about how each of the games that they play are rated. Then respondents were asked for what fraction of those games did respondents know their ratings. Respondents were given a scale that included the possible responses of "none of the games," "about a quarter of the games," "about half of the games," "about the three-quarters of the games," and "all (or nearly all) of the games." Along a similar path, I asked respondents whether they had ever bought a video game rated "M" or "AO" before the age of 18 . The possible responses for this question were "no, I have never purchased a game rated M or AO," "no, I never tried to purchase video games rated M or AO before I was 18," and "yes, I did purchase video games rated M or AO before I was 18." This was followed by a "yes" or "no" question that asked if a video game vendor has ever asked for identification before purchasing a video game. 


\section{Perceptions of Video Game Violence}

Another question that was reserved for those respondents who had played video games in the past five years asked for a rating on a five point scale of the average level of violence for the video games that the respondent plays. This scale ranged from "Hardly any violence" to "Graphically and disturbingly violent."

If respondents did not play video games, they skipped those self-report questions about gaming behavior. All respondents were asked questions about their attitudes toward regulations. The first of these questions described the ratings system and then asked respondents whether they felt regulations were necessary to prevent the sales of M or AO rated games to minors. Respondents could answer either "yes," "no," or "I don't know." Next, respondents were asked whether the government should regulate video game content. Respondents could respond that "The government should regulate the content of video games," or "The government should not regulate the content of video games." The last question in this section explained how there have been court cases in which an individual committed an act of violence and claimed that he was acting out a scene in a violent video game. Respondents were then asked whether they felt victims of this type of imitative violence should be able to sue video game manufacturers. Respondents could answer "Yes, they should be allowed to sue to recover damages," "No, they should not be allowed to sue to recover damages," or "I'm not sure; there are valid arguments on both sides."

I asked all respondents about their perceptions of violence in real life in relation to video gaming habits. This question asked for the extent to which respondents perceived violent video games to be responsible for an increase in violent behavior in real life. Respondents could reply with "There has not been a significant increase in violent behavior in real life," "Not at all," "To a small extent," "A 
moderate amount," "To a great extent," and "Almost all violence in real life is instigated by video games.” For a full list of questions, see Appendix A.

\section{Demographic Data}

I also asked a series of demographic questions. I asked about their gender, age, level of education, religion and household income. I ascertained their political beliefs by asking for whom they voted in the 2008 Presidential election.

The final question of the survey was open-ended and it asked for any additional comments the respondent might have. Overall, the survey consisted of 28 questions. Two were open-ended (the first asked for titles of respondents' favorite video games) and six were demographic questions.

After the survey was closed in December, the responses were run through SPSS analysis software to determine statistical significance.

\section{$\underline{\text { Limitations }}$}

There are several limitations to this methodology. First is the way in which the sample was selected. The results of this research reflect only the opinions of a convenience sample. While the sample size is large, because it was not a random sample, it is difficult to know how representative it was of the population as a whole.

In addition, I was surprised to find that a large portion of the respondents were Catholic (34\%). Approximately $25 \%$ of the population in Delaware is Catholic so this sample is not representative of the United States population. It may reflect the population of Delaware, but not the United States. In addition, 56\% of respondents reported that they voted for Barack Obama in the November 2008 Presidential 
election. 50\% reported that they are in college and 37\% reported attaining a 2-year, 4year, or graduate degree. The majority of my sample, therefore, is liberal and educated.

Second, the survey did not define violence for the respondents. I felt that by defining violence for those taking the survey, it would create a bias in their responses or limit the data. Since people have different perceptions of violence, this could skew the data. However, by allowing people to interpret the survey as they wished, I hoped that the responses were more honest and representative of what the individual respondents believe violence is, instead of what I think it is.

Another major limitation to this research is the nature of the survey. Selfreport data is naturally subject to questionable validity. It is possible that respondents who play video games with more frequency will be more sympathetic to the video game industry, thereby boosting their perceptions of the benefits that playing video games has had on their lives. When analyzing the results, it is important to keep in mind that the data could reflect a bias in the responses. 


\section{Chapter 4}

\section{RESULTS}

I used the Statistical Package for the Social Sciences (SPSS) software to analyze the data.

\section{Benefits of Games}

Before analyzing respondents' attitudes toward video game censorship, I felt that it was necessary to find out if the respondents believed that there are significant benefits resulting from playing video games. If respondents believed that playing video games enriched their lives, then it would be necessary to weigh that fact against how they felt about video game censorship.

To test this, some of the first questions in the survey were about the benefits of video game play. I first asked respondents whether they played video games. If they did, they were asked the approximate number of hours that they played per week on a scale ranging from $0-1,2-5,6-10,11-15,16-20,21+$. To scale the level of benefit that gaming has had on respondents, the questions were framed as "Not at all," "A small amount," "A moderate amount," and "A great deal." Of the 345 people who took the survey, 322 answered that they have played video games in the past five years. Therefore, for these questions about benefits, $\mathrm{N}=322$.

Of the 322,199 people saw at least some improvement in their reaction time, or 61.8 percent of the sample. To calculate the significance for this question, I compared the number of people who played 0-5 hours per week with the number of 
people who played six hours or more per week. I compared the respondents in this way because I felt that those who play five hours or less per week are more casual players while people who play six hours or more per week are more serious "gamers." Splitting the data in this way was a personal decision, without a scientific basis. Those who play five hours per week or less will be referred to as low level players and those who play six or more hours will be referred to as high level players.

I compared these value sets with people who did not see any improvement in reaction time against people who saw at least some improvement. High level players are more likely than low level players to report an improvement in their reaction times. Of the high level players, 95.4 percent reported an improvement in reaction time while only 53.3 percent of low level players reported an improvement. The difference in the likelihood of reporting an improvement is significant $\left(x^{2}(1)=38.908, \mathrm{p}<0.001\right)$. 
Table 1 Graph of hours per week and reaction time improvement.

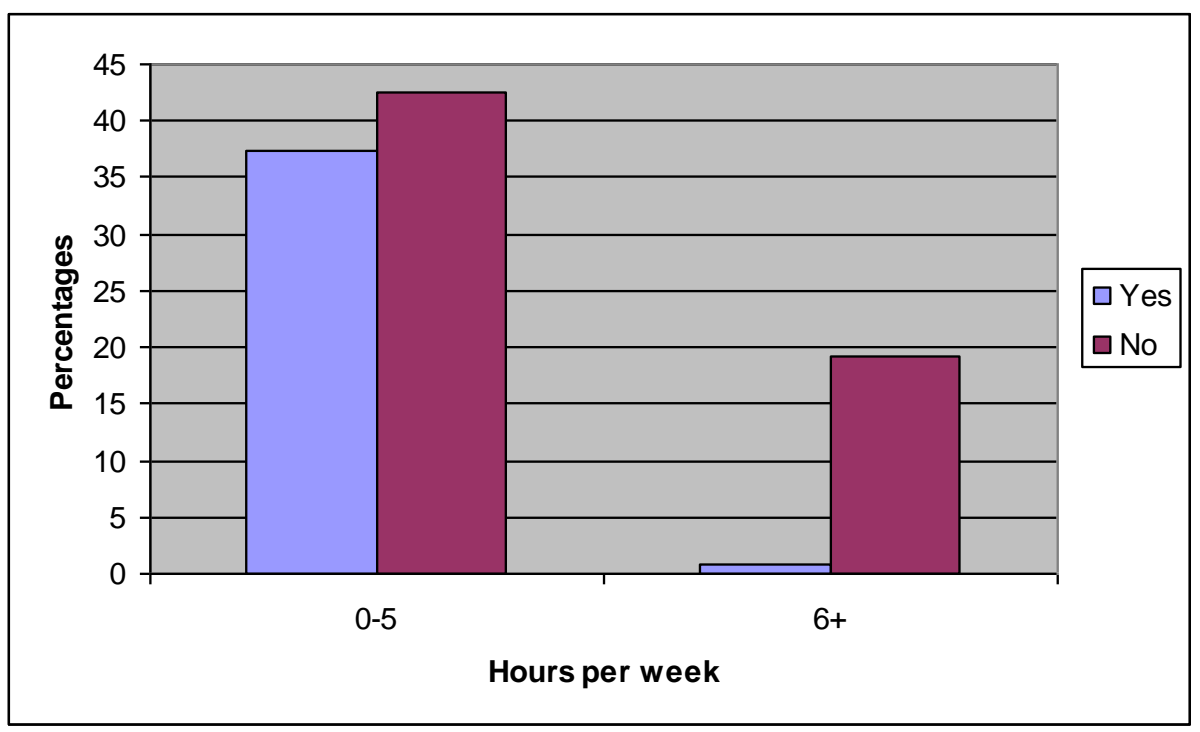

The next question asked about whether respondents had noticed an

increase in or expansion of their social network. Using the same distinctions for high and low level players, I compared the likelihood of reporting an improvement in social network for both levels. While only 49.7 percent of respondents reported an improvement in social network, 31.5 percent of that population consisted of low level players. 39.5 percent of low level players reported an improvement in social network whereas 89.4 percent of high level players reported that improvement. The difference in the likelihood of reporting an improvement in social network was significant $\left(x^{2}(1)\right.$ $=52.262, \mathrm{p}<0.001)$. 
Table 2 Graph of hours per week and reported social network expansion.

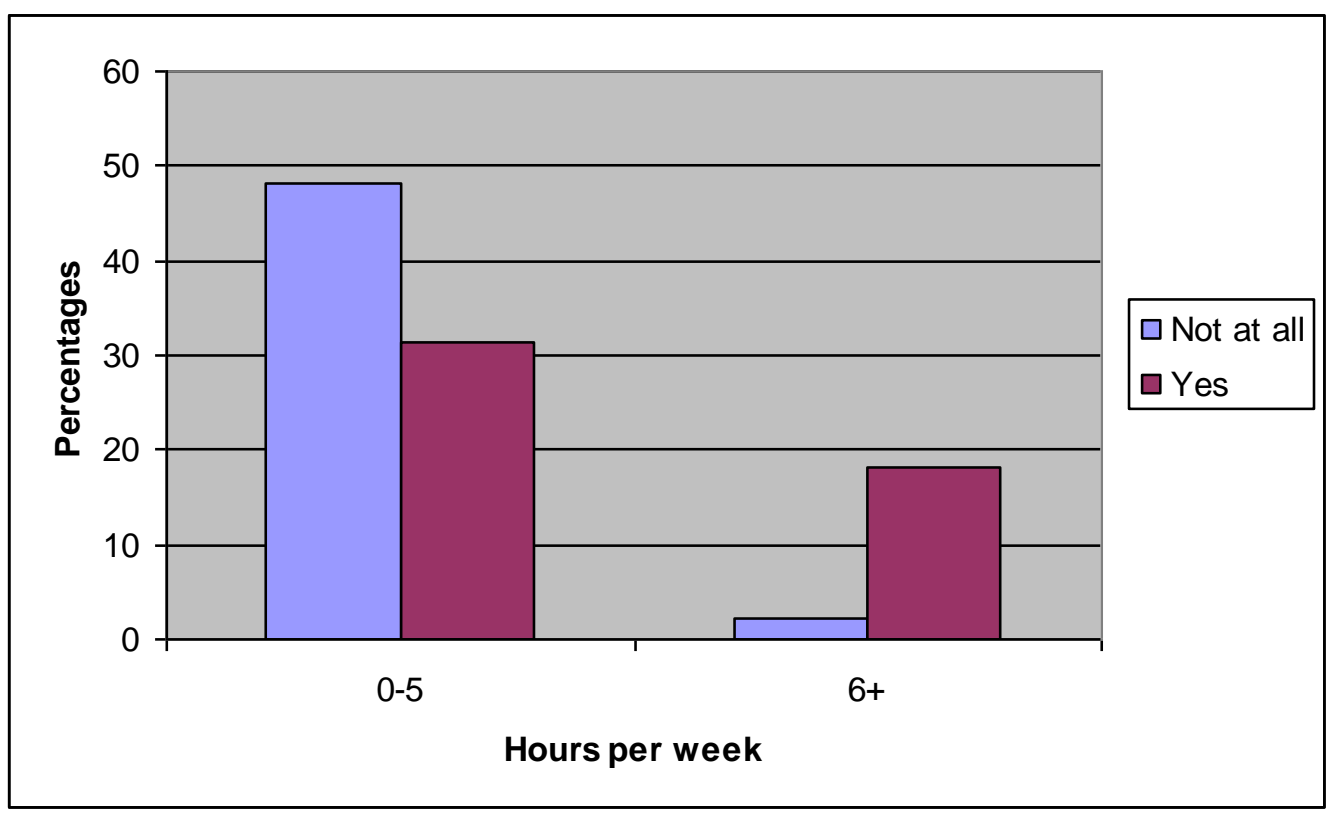

These questions regarding benefits of video games were important because they could help gauge the respondents' attitudes toward censorship. If respondents believed that they have benefited from playing video games, then that would be weighed against their perception of any potential harm that games could cause.

\section{How frequently people play as related to desired levels of restrictions}

H1 claimed that the more people play video games, the more sympathetic they would be with manufacturers, meaning they would like to see fewer restrictions, less government interference, and no liability for manufacturers in the judicial system. The results did not totally support this hypothesis.

Respondents were first asked about ratings. Whether they played video games for 0-5 hours or 6 or more hours per week, respondents felt that the ratings system is necessary (see Table 3). Sixty-nine percent of respondents answered "yes" when asked if they felt that the ratings system is necessary. The Pearson chi-square test 
did not indicate a significant difference between high and low levels of players $\left(x^{2}(1)=\right.$ $0.041, \mathrm{p}>0.05)$. This analysis does not support H1.

Table 3 Hours played per week cross tabulated with whether the ratings system is perceived as necessary.

\begin{tabular}{|ll|l|l|l|}
\hline \multirow{2}{*}{} & \multicolumn{2}{|l|}{ regulations--ratings? } & \multirow{2}{*}{ Total } \\
\cline { 3 - 5 } & Yes & No & 186 \\
& $0-1$ & 135 & 51 & 65 \\
& $2-5$ & 37 & 28 & 28 \\
& $6-10$ & 19 & 9 & 21 \\
& $11-15$ & 16 & 5 & 4 \\
Total & $16-20$ & 3 & 1 & 9 \\
\hline
\end{tabular}

I then asked respondents about their feelings towards government regulation. No matter how many hours respondents played per week, the majority responded that "No, the government should not be involved in regulating video game content." In addition, 100 percent of the respondents who play an average of 16 hours or more per week felt that the government should not interfere in the video game industry. The more hours per week that people play video games, the more likely they were to report that they feel that governmental regulation was uncalled for. A chisquare test revealed a significant difference in the likelihood of high level players and low level players reporting that the government should not regulate the video game industry $\left(x^{2}(5)=20.789, \mathrm{p}<0.01\right)$. 
Table 4 Graph of hours per week and a perception of government regulation.

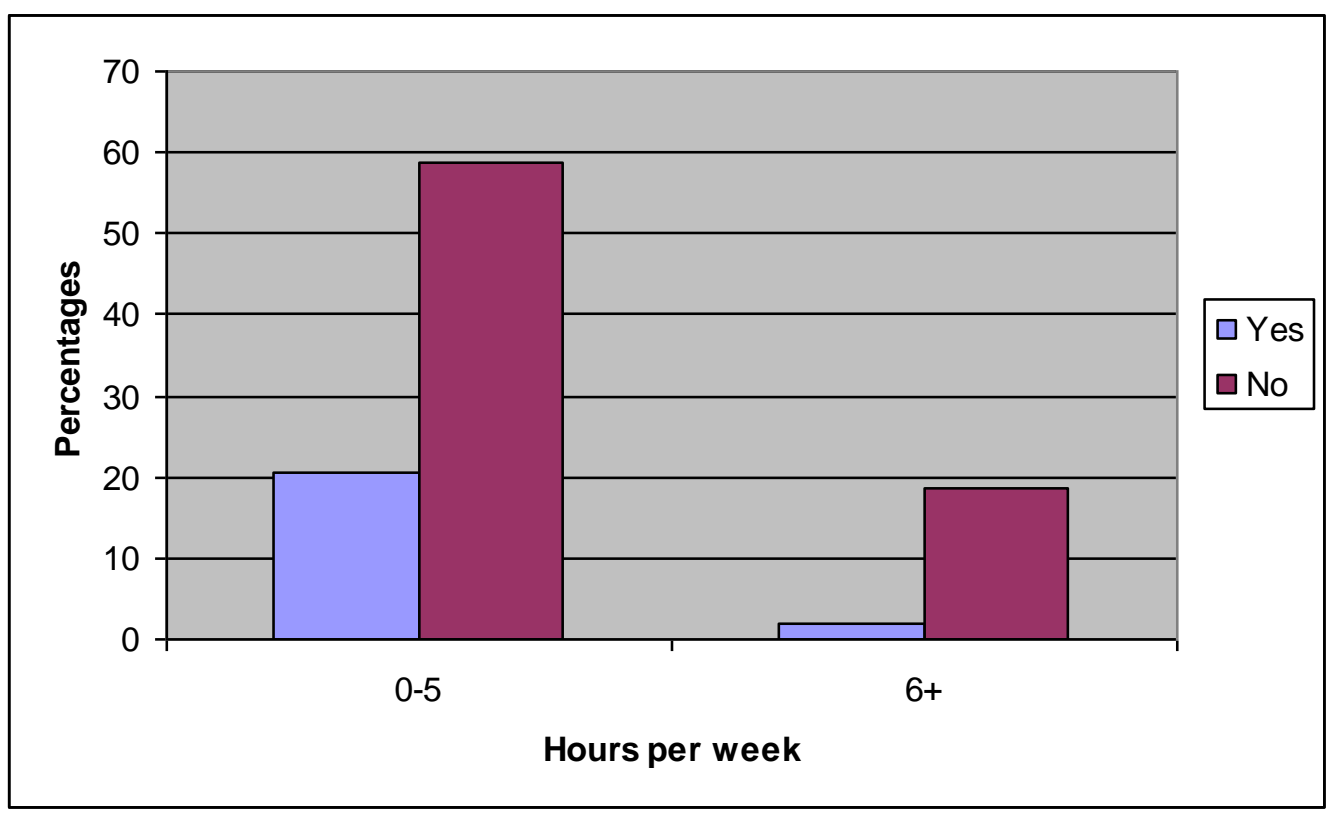

Finally, the survey asked respondents whether they felt that manufacturers should be held liable in court for cases of copycat violence. This question added an option of "I'm not sure." The majority of respondents felt that manufacturers should not be held liable in cases of imitated violence. Of the 315 people who responded to both of these questions, 14 said yes, manufacturers should be held liable, 228 said manufacturers should not be held liable and 73 said that they were not sure. Of the low level players (0-1 for this analysis), 64 percent said that victims should not be allowed to sue manufacturers for damages. This is compared to 80 percent of medium level players (2-5 hours per week) and 89 percent of high level players (6+ hours) who did not think that victims should be able to sue. A Pearson chi-square test of the relationship was significant $\left(x^{2}(4)=17.800, p=0.001\right)$. In other words, the high level players were more likely than low level players to report that victims of imitated violence should not be able to sue video game manufacturers for damages. Table 5 
shows how the data overwhelmingly favor those who feel that manufacturers are not liable for cases of copycat violence.

Table 5 Evaluation of hours per week and attitudes about whether victims of imitated violence should be able to sue manufacturers for damages.

\begin{tabular}{|c|c|c|c|}
\hline & Value & $d f$ & $\begin{array}{l}\text { Asymp. Sig. (2- } \\
\text { sided) }\end{array}$ \\
\hline Pearson Chi-Square & 17.800 & 4 & .001 \\
\hline Likelihood Ratio & 19.426 & 4 & .001 \\
\hline Linear-by-Linear Association & 7.477 & 1 & .006 \\
\hline $\mathrm{N}$ of Valid Cases & 315 & & \\
\hline
\end{tabular}

$\mathrm{p}<0.01$

Considering these results, $\mathrm{H} 1$ is both supported and unsupported. The majority of respondents agreed that the ratings system is a valuable mechanism, which does not support H1. On the other hand, people overwhelmingly felt that the government should not regulate video game content and that victims of copycat violence should not be able to hold the manufacturers of video games liable for that violence. High level players were more likely than low level players to report that they did not think that the government should not be involved and that victims of imitated violence should not be able to sue for damages.

\section{How responsible are video games for violence in real life?}

The next level of analysis that was required for this project was to test $\mathrm{H} 2$ and H3. These claimed:

$\mathrm{H} 2$ : People who believe that video game violence instigates violence in real life will also believe that government censorship is necessary. 
H3: People who believe that video game violence instigates violence in real life will also believe that victims of copycat violence should be able to successfully sue video game manufacturers for damages.

To test these two hypotheses, respondents were first asked how much they felt video game violence contributed to violence in real life. Respondents were given a five point scale, ranging from "not at all" to "a great deal."

Most people reported that they felt that the government should not be involved in video game censorship or regulation. Only 35 percent of respondents reported feeling that the government should play a role in regulating the video game industry, whereas 65 percent did not. The more people believe that video games instigate violence in real life, the more likely they are to report that the government should have the ability to regulate the industry. A chi-square test of these two variables revealed that the difference in beliefs about the government's role is significant $\left(x^{2}(1)\right.$ $=3.915, \mathrm{p}<0.05)$. Table 6 shows a positive correlation between the belief that violent content in video games can instigate violence in real life, and the belief that the government should regulate violent content in video games. 
Table 6 Effects on real life violence cross tabulated with a perception of governmental regulation.

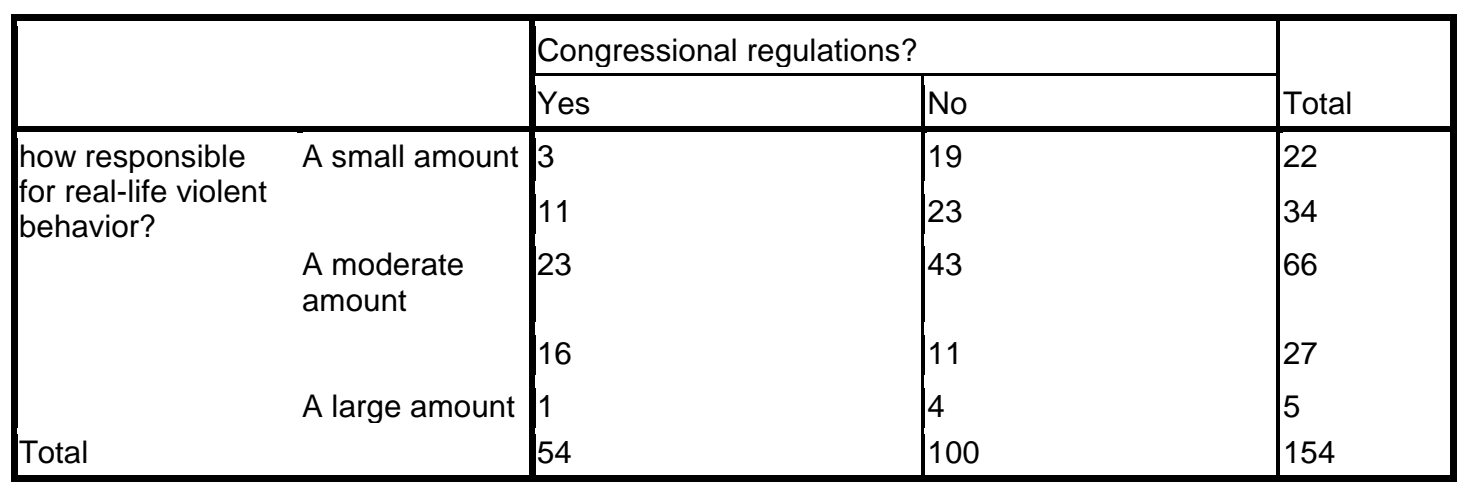

Next, I found that most people feel that video game manufacturers should not be held liable in cases of copycat violence. Again, the more people felt that video game violence can trigger violence in real life, the more likely they were to agree that video game manufacturers should be held responsible. Seven percent of respondents felt that video game manufacturers should be held responsible, 60 percent felt that they should not, and 33 percent were unsure, $x^{2}(2)=6.947, \mathrm{p}<0.05$. People who agree that violence in video games can trigger violence in real life were more likely to sympathize with manufacturers in the courtroom than people who do not think that violence in video games instigates violence in real life. 
Table 7 Graph of effects on real life violence and whether victims of imitated violence can sue manufacturers.

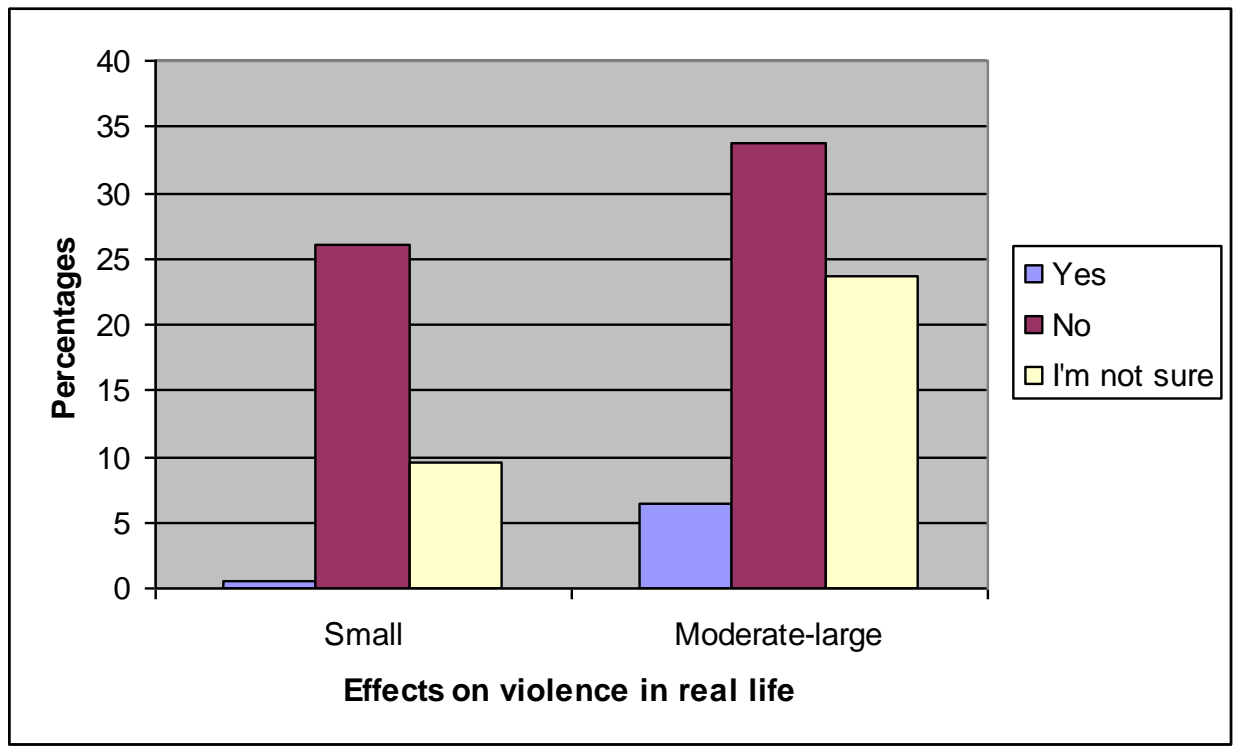

These tests show that $\mathrm{H} 2$ and $\mathrm{H} 3$ are supported. Even though most people lean in favor of the manufacturers and not in favor of the victims of copycat violence, people who agree that violence in video games instigates violence in real life are more likely to believe that the government should be involved and that victims should be able to sue manufacturers. On the other side, those who did not believe that violence in video games affects violence in real life were more likely to resist government involvement and judicial sanctions. Despite this, the majority of respondents still felt that the manufacturers still have the right to produce any video game content they like.

\section{Gender sympathy}

H4 stated that women would be more sympathetic to victims of copycat violence than would men. The hypothesis, therefore, claims that women will be more inclined than men to support the ratings system, government regulation, and judicial 
sanctions on video game manufacturers. There were 195 women and 143 men who responded to these questions.

As discussed above, most of the respondents felt that the ratings system is important. When asked about ratings, 151 women (77.4 percent) believed that the ratings system is necessary while 87 men (60.8 percent) agreed. Comparatively, 44 women ( 22.6 percent) and 56 men (39.2 percent) did not think that ratings were necessary. Women are therefore significantly more inclined than are men to report that the ratings system is necessary $\left(x^{2}(1)=10.908, p=0.001\right)$. There was a significant difference between the men's and women's attitudes toward video game ratings.

Table 8 Graph showing gender support for the ratings system.

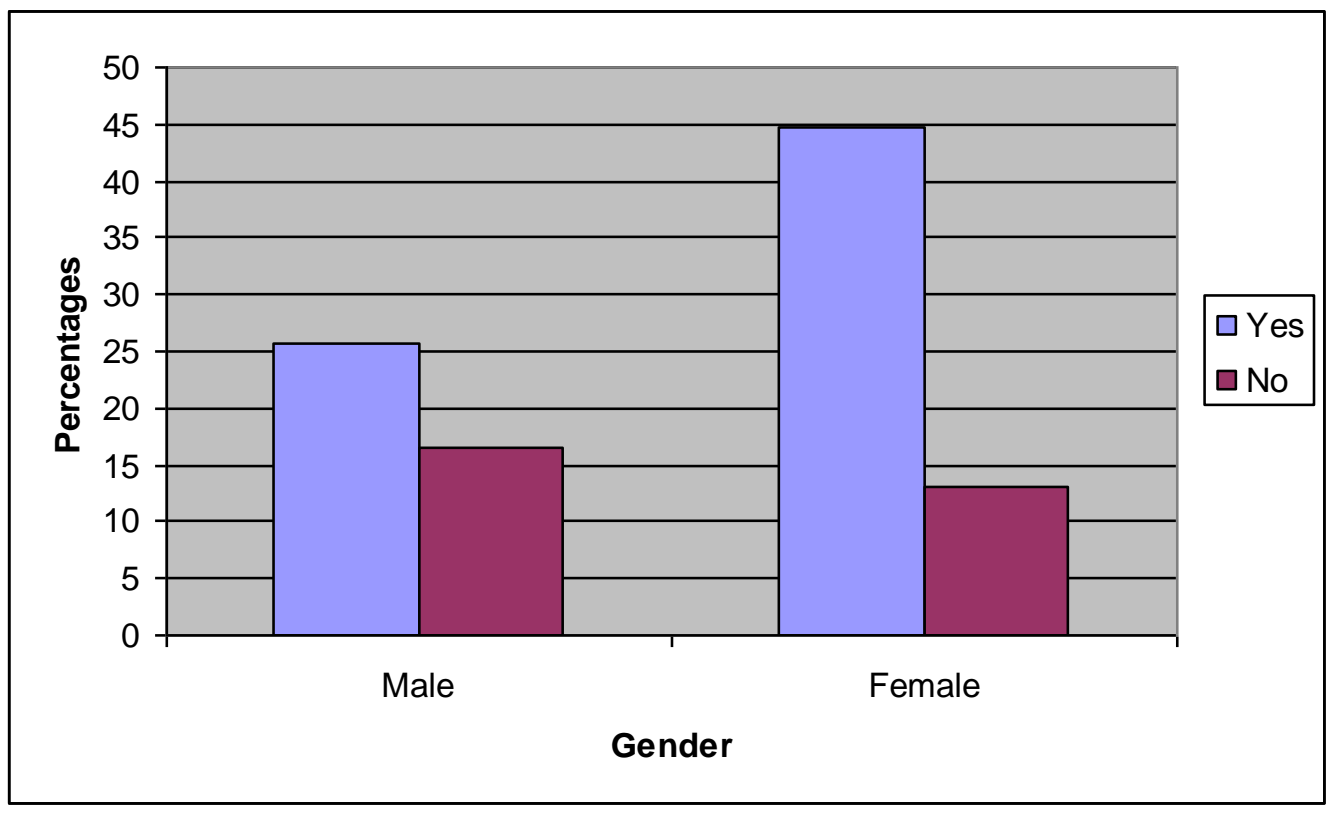

The next question about video game restrictions asked whether video game content should be regulated by Congress or the Federal Trade Commission. Sixty-seven women (34.2 percent) and 14 (9.8 percent) men felt that the government 
should be able to regulate video game content. Alternatively, 127 women $(64.8$ percent) and 129 men (90.2 percent) felt that the government should not regulate content in the video game industry at all. While most people taking the survey felt that the government did not have an effective means of regulating video games, women were more likely than men to agree with government regulation, $x^{2}(1)=27.609, \mathrm{p}<$ 0.001 .

The final question regarding federal restrictions on video games was concerning the role of the courts. $\mathrm{H} 4$ also claims that more women than men will be sympathetic with victims of copycat violence in the judicial system. In support of H4, 11 women felt that victims of copycat violence should be allowed to successfully sue for damages while only three men agreed. On the other hand, 119 women and 124 men felt that victims should not be allowed to sue for damages. This question also allowed respondents to answer that they were unsure of the answer. Sixty-six women and 16 men chose this response. Considering how many more women than men responded to these questions, there is a significant difference in the female and male response rate in support of a victim's ability to sue for damages $\left(x^{2}(1)=27.609, \mathrm{p}<0.001\right)$. More women felt that victims should be allowed to recover damages in cases of copycat violence. 
Table 9 Graph of gender and victim ability to sue.

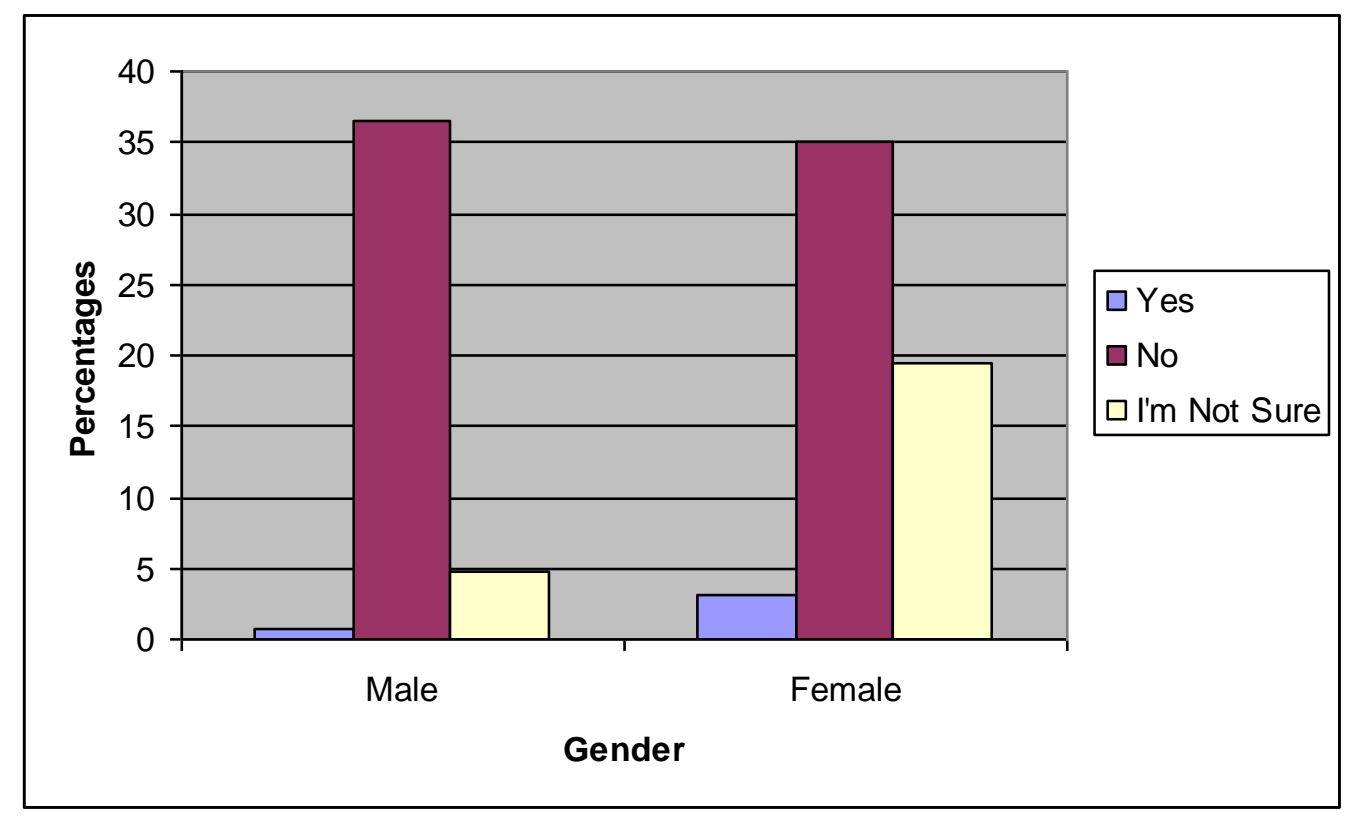

H4 is supported by all three levels of this analysis.

\section{Do ratings work?}

It is clear from the survey responses that most people feel that the only restriction on video games that should be in existence is the ratings system. According to the respondents, governmental regulation and judicial sanctions are inappropriate with regards to the video game industry. I also wanted to determine how successful the respondents thought the ratings system is in preventing minors from obtaining video games containing graphic sex and violence. To do this, the survey asked respondents whether they had ever attempted to purchase a video game rated "M" or "AO" before the appropriate age. Those who responded yes were then asked if they were successful in their attempt. Finally, respondents were asked if they had ever been asked for identification when purchasing a video game. 
The first question in this series asked whether respondents had ever tried to purchase a video game rated "M" or "AO" before they turned 18. Out of 320 respondents who answered this question, only 113 (35.3 percent) answered "yes," they had tried to purchase video games above their age-appropriate rating. Respondents who answered yes were then asked if they were successful in purchasing a video game rated "M" or "AO" before they were 18-years-old. Ninety-four (83.1 percent of 113) people answered that they were successful, meaning that they bought $\mathrm{M}$ or AO-rated games before they were legally permitted to do so.

The ratings system was not implemented, however, until 1994, 15 years ago. Therefore, respondents who were 33 years old or older could have tried to purchase an inappropriate game before the ratings system was implemented. Table 27 shows that only two of the 94 people who were successful tried to purchase an inappropriate video game before the ratings system went into effect. The other 92 respondents were acting illegally according to the federal legislation that required retailers to restrict sales of video games according to their ratings.

Table 10 Age cross tabulated with whether respondents tried to purchase an "M" or "AO" game before 18.

\begin{tabular}{|c|c|c|c|c|c|c|}
\hline & \multicolumn{5}{|l|}{ Age: } & \multirow[b]{2}{*}{ Tota } \\
\hline & 18-19 & $20-21$ & $22-24$ & $25-30$ & $31+$ & \\
\hline $\begin{array}{l}\text { Before you were 18, did } \\
\text { you ever succeed at } \\
\text { purchasing a video game No } \\
\text { rated "M" (Mature) or } \\
\text { "AO" (Adult Only)? }\end{array}$ & $\begin{array}{l}24 \\
6\end{array}$ & $\begin{array}{l}52 \\
9\end{array}$ & $\begin{array}{l}14 \\
3\end{array}$ & $\begin{array}{l}1 \\
0\end{array}$ & 2 & $\begin{array}{l}93 \\
18\end{array}$ \\
\hline Total & 30 & 61 & 17 & 1 & 2 & 111 \\
\hline
\end{tabular}




\section{Open Ended Responses}

One of the most illuminating aspects of the survey was the last question. It asked respondents to record any last comments that they might have about video games and video game violence. Seventy-seven people chose to leave an extra comment at the end of the survey. A content analysis of these responses showed some interesting results.

The most common trend in these open-ended responses was the attitude that parents are the ones that need to take responsibility for their children's actions. Twenty-three people mentioned the need for parents to monitor their children's gaming habits more carefully. One respondent commented that:

I am an X generation gamer, playing video games for at least 25-30 years (starting with Atari)... I have three children under 10. In my opinion, it is MY responsibility as a parent to monitor what my children play as far as video games. Knowing the graphic nature of some of the games... I know first hand what these games can do to the minds of children. That being said, it is the sole responsibility of the PARENTS to ensure their children are not playing games that can influence them in a negative manner" (anonymous survey 2009).

This father feels that the government does not have a role in keeping children from playing inappropriate video games. He claims, as many of the respondents did, that it is the parents' responsibility to watch their children and their children's gaming habits. Unfortunately, parents do not always attend to the ratings restrictions. Another respondent told a story of a parent he saw buying inappropriate games for her children:

Once in a GameStop I saw a mother holding three $\mathrm{M}$ rated titles to purchase for her nagging child. This child could not have been older than ten, and the titles he wanted his mother to buy for him included Grand Theft Auto IV, Halo 3, and Devil May Cry 4... The rep at the counter asked several times if she was sure she wanted to purchase these games for her child because of the content and warned her that the 
games were $\mathrm{M}$ for a reason. She ignored all of this and bought the games anyway (anonymous survey 2009).

While 23 of the respondents felt strongly enough to leave comments about the need for responsible parenting, it is clear from this response that parents are not always going to pay attention to what would be an appropriate game for their children.

Many respondents wrote that the individual should be held accountable. Nine respondents mentioned that people should take responsibility for themselves. Along the same lines, four respondents felt that criminals are using video game manufacturers as scapegoats for their own violent actions. One such respondent says:

Sometimes I feel that the people who sue game companies are coerced into doing so by lawyers who know that those companies have large reserves of money. They get the child to confess that he/she was influenced by violent games and then claim to be the reason why he/she attacked people at his/her school. It's a convenient cop-out for the child and a windfall of pure profit for the lawyer. Jack Thompson [former lawyer for the Strickland v. Sony case], a disbarred Florida lawyer, is one example of this type of person... I believe that the people who claim they were influenced by games to kill people are full of it (anonymous survey 2009).

Many of the people who took the survey felt strongly that parents or the people committing the acts of violence are the ones who should be held accountable and that they should not blame video games for their own acts of violence.

Twenty-one respondents believed, however that video games can affect people's behaviors if they have a natural predisposition towards violence or if there are other factors influencing the person's attitude. For example, one respondent explained that:

I believe that while violent video games are responsible for making a person more violently-minded, they are not enough to cause a person to commit an act of violence by themselves. Only when combined with other factors (family issues, drug/alcohol abuse, psychological 
problems) will the influence of video games be realized... therefore video game manufacturers cannot be held responsible for an act that a person committed due to a [combination of factors] (anonymous survey 2009).

This response reflects what much of the psychological research has already shown. Many of the people who are predisposed towards violence and violent acts have come from a broken home, were physically or emotionally abused, or were exposed to drug and alcohol abuse. Most medical and psychological research supports what this respondent claims. One of the respondents claims that he has been playing video games since "about the age of 7" and then went on to work in the industry for two years. He acknowledges that video games can be blamed for violence to an extent. He agrees, however, that those affected by video game violence often have other issues that need to be considered (anonymous survey 2009). A common thread throughout these open-ended responses is that when people are affected by video games, it is because there are other factors involved and it is not just due to the graphic violence in first-person shooter games.

The content analysis table (Table 11) shows the types of responses that people gave in the open-ended section. Twelve people felt that video game violence is no different from the violence in movies or on television. One respondent even compared the violence in video games to his history textbook (anonymous survey 2009). Seven people feel that the video game violence controversy is not an actual issue. Of all of these responses, only four believed that video games do cause increased violence in real life and five commented that video games cause desensitization to violence in real life. Only two people commented that video games need to be monitored more closely. 
Table 11 Content Analysis of Open Ended Responses

\begin{tabular}{|l|l|}
\hline Type of Answer & Number \\
\hline Parent's responsibility & 23 \\
\hline Natural pre-disposition to violence & 13 \\
\hline It's the same as violent music or movies & 12 \\
\hline People need to take responsibility for own action & 9 \\
\hline Due to a number of factors & 8 \\
\hline It's not an issue & 7 \\
\hline Causing desensitization to violence & 5 \\
\hline People need a scapegoat & 4 \\
\hline Do cause violence & 4 \\
\hline I appreciate video games & 4 \\
\hline Video games are not violence for its own sake & 3 \\
\hline Video games should be regulated more closely & 2 \\
\hline
\end{tabular}




\section{Chapter 5}

\section{CONCLUSIONS}

Of the 345 respondents who completed this survey, the great majority made it clear that they believe that the arguments for First Amendment protection outweigh the arguments for censorship of video games. Most people felt that the government should not regulate the video game industry any more than it already does. In addition, respondents believe that victims of copycat violence should continue to seek redress in places other than the courtroom. Precedent and popular opinion hold that the First Amendment protects video game content.

Of the four hypotheses for this project, only $\mathrm{H} 1$ was not completely supported. H1 claimed that the more frequently people play video games, the more sympathetic they will be with video game manufacturers. While people felt that further government regulation and judicial sanctions would be inappropriate, the majority of respondents reported feeling that the ratings system that is already in place is much needed. Because nearly all of the respondents had a favorable attitude toward the ratings system, $\mathrm{H} 1$ is not completely supported. The results of the survey, however, showed that the ratings system is not a completely reliable means of restricting minors' access to $\mathrm{M}$ and AO-rated games. Many of the respondents revealed that they were able to get by the ratings system and purchase inappropriate games for themselves when they had been under age. In addition, as one of the open-ended responses showed, parents do not always acknowledge the ratings, even when video game 
vendors attempt to restrict children's access to graphic sex and violence in M and AOrated games.

The results of the survey supported $\mathrm{H} 2$ and $\mathrm{H} 3$ but not as strongly as was expected. Even though there were those who felt that video game violence instigates violence in real life, the overwhelming majority of respondents did not believe that Congress or the Federal Trade Commission should have any influence over the video game industry, nor should victims of imitated violence be able to sue manufacturers for damages. The only restriction with which most respondents agreed was the ratings system which is already in place and which has been shown to be flawed in terms of whether retailers and parents abide by it or not.

$\mathrm{H} 4$ is the only hypothesis that is supported as expected. Women were more sympathetic than men to those who agree with restrictions on the video game industry. While most women still felt that the First Amendment takes precedence, there were significantly more women than men who believed that the ratings system should be enforced, that Congress and the Federal Trade Commission should have an influence in the video game industry, and that manufacturers should be held liable for cases of copycat violence.

While most of the psychological research proves that video game violence can have a negative impact on the cognitive functioning of children, the country is not yet in a place in which it is willing to sacrifice First Amendment protection for violent video games. Instead, respondents pointed to parents to monitor their children. The respondents also felt that victims and legislators need to stop pointing to video games as a scapegoat for the violent acts that very disturbed individuals commit. Most of the findings of the psychological research suggest that while video games affect most 
players in some way, only those who are already emotionally disturbed will be likely to recreate that video game violence in the real world.

Because public opinion, according to this sample, dictates that First Amendment protection for violent content takes precedence over concerns for the cognitive processing of adolescent gamers, a new solution needs to be found. According to the Federal Trade Commission, the best way for the industry to be regulated is through self-monitoring. The industry has already begun to restrict minors' access to $\mathrm{M}$ and AO-rated video games by continuing to encourage retailers to abide by the ratings system guidelines. While the results of the FTC mystery shops outlined in Chapter 2 reveal that minors still have high levels of access to inappropriate video games, each year the percentage of shoppers who are able to purchase these games decreases. Public opinion shows that people would prefer the video game industry continue to encourage retailers and parents to comply with the ratings system restrictions than rather than having the government become involved.

These results suggest that the U.S. Supreme Court will strike down as unconstitutional the California law prohibiting sales of violent video games to minors. People feel that it is the role of the parents, and not the legislatures, to make rules about what children are playing. 


\section{REFERENCES}

Altman, A. et al. (2009, May 4). Briefing. Time Magazine, 15

American Academy of Pediatrics. (2000, July 26). Joint statement of the impact of entertainment violence on children, Congressional Public Health Summit. Retrieved from http://www.aap.org.

American Amusement Machine Association v. Kendrick, 244 F. 3d 572 at 576 ( $7^{\text {th }}$ Cir. 2000).

Anderson, C. (2003). Violent video games: Myths, facts and unanswered questions. Retrieved from http://www.apa.org/science/psa/sb-andersonprt.html.

Bradley, E. (2005). Can a video game lead to Murder? Retrieved from http://www.cbsnews.com.

Brandenburg v. Ohio, 395 U.S. 444 at 448 (1969).

Bureau of Justice Statistics. (2010). Four measures of serious violent crime. Retrieved from http://bjs.ojp.usdoj.gov.

Calvert, C. and Richards, R.D. (2005). Mediated images of violence and the First Amendment: From video games to the evening news. Maine Law Review 57, 91-116.

Calvert, C. and Richards, R. D. (2004). The 2003 legislative assault on violent video games: Judicial realities and regulatory rhetoric. Villanova Sports \& Entertainment Law Forum, 11, 203-270.

Child-Responsible Media Campaign. (2006). A summary of the violent media legislation in the United States. Retrieved from http://www.medialegislation.org.

Dahl, R. E. (2004) Adolescent brain development: A period of vulnerabilities and opportunities. 1021 Annals of the New York Academy of Science, Adolescent Brain Development: Vulnerabilities and Opportunities 1 (R. E. Dahl \& L.P. Spear, Editors). 
Dubow, E. F., Huesmann, L. R., \& Eron, L. D. (1987) Childhood correlates of adult ego development. Child Development, 58 (No. 3), 859-869.

Entertainment Software Ratings Board. (2009). Game ratings and descriptor guide. Retrieved from http://www.esrb.org.

Federal Trade Commission (FTC). (December 2001). Marketing violent entertainment to children. Retrieved from http://www.ftc.gov/os/2001/12/violencereport1.pdf.

Federal Trade Commission (FTC). (30 March 2006). Undercover shop finds decrease in sales of M-rated video games to children: Results from the 2005 nationwide undercover shop demonstrate need for continuing improvement. Retrieved from http://www.ftc.gov/opa/2006/03/videogameshop.shtm.

Felson, R. B. (1996). Mass media effects on violent behavior. Annual Review of Sociology, 22, 103-128.

Garabino, J., \& Bradshaw, C. P., \& Vorrasi, J. A. (2002). Mitigating the effects of gun violence on children and youth. The Future of Children, 12 (No. 2), 73-85.

Grossman, D. \& DeGaetano G. (1999). Stop teaching our kids to kill: A call to action against TV, movie and video game violence. New York: Crown Publishers.

Holland, J. J. (26 April 2010). Court to decide if state can regulate video games. AP Newswire. Retrieved from news.yahoo.com/s/ap.

Hurley, S. (2004). Imitation, media violence, and freedom of speech. Philosophical Studies, 117, 165-218.

Lambe, J. L. (2002). Dimensions of censorship: Reconceptualizing public willingness to censor. Communication Law and Policy, 7 (No. 2), 187-235.

Leonard, J. (1995). The negative impact of media violence on society is exaggerated. In B. Leone, Editor, Violence in the media, 31-37. San Diego, California: Greenhaven Press.

Li, W. (2003). Unbaking the adolescent cake: The constitutional implications of imposing tort liability on publishers of violent video games. Arizona Law Review, 45, 457-505.

James v. Meow Media, Inc. 300 F.3d 683, (6th Circuit Court of Appeals 2002). 
MacKenzie, A. H. (2005). The brain, the biology classroom \& kids with video games. The American Biology Teacher, 67 (No. 9), 517-518.

Matheson, J. (2008, May 7). H.R. 5900, $110^{\text {th }}$ Congress 2 d Session.

Miller v. California, 413 U.S.15 at 21 (1973).

PR Newswire. (2009, Nov. 18). Call of Duty®: Modern Warfare® 2 sets all-time entertainment industry record grossing and estimated $\$ 550$ million worldwide in first five days. Retrieved from http://investor.activision.com.

Reeves, T. D. (2009). Tort liability for manufacturers of violent video games: A situational discussion of the causation calamity. Alabama Law Review, 60, 519-546.

Saunders, K. W. (2005). A disconnect between law and neuroscience: Modern brain science, media influences and juvenile justice. Utah Law Review, 2005, 695741.

Singer, D. \& Singer, J. (2005). Violent themes in play, TV content, and video games. Imagination and play in the electronic age. Cambridge, Massachusetts: Harvard University Press.

Video Software Dealers Association v Maleng 325 F. Supp. 2d 1180 (W.D. Wash. 2004).

Video Software Dealers Association v. Schwarzenegger 556 F.3d 950 (Court of Appeals $9^{\text {th }}$ Cir. 2009).

Williams, D. Caplan, S. \& Xiong, L. (2007). Can you hear me now? The impact of voice in an online gaming community. Human Communication Research, 33, 427- 449 . 


\section{Appendix A}

\section{SURVEY QUESTIONS}

\section{DO NOT COMPLETE THIS SURVEY IF YOU ARE UNDER AGE OF 18}

1. Do you play or have you played video games in the past five years?

Yes No

2. Please list your 5 favorite video games.

1.

2.

3.

4.

5 .

5. Approximately how many hours per week do you play video games?

$0-1$ $2-5$ 6-10 11-15 16-20

$21+$

6. Has your reaction time improved as a result of playing video games?

Not at all

A small amount

A moderate amount

A large amount

7. How much have video games helped you expand your social network or group of friends?

Not at all

A small amount

A moderate amount

A great deal

8. Do you find that playing video games has helped you enhance any skills? 
Yes No Somewhat

9. Do you find that playing video games has had any other benefits for you? If so, please explain.

Yes (explain)

No

10. Video games are given a rating between "E" for everyone to "AO" for adults only. Of the video games that you play, think about how each one is rated. For what fraction of those games do you know their ratings?

None of the games

About a quarter of the games

About half of the games

About three-quarters of the games

All (or nearly all) of the games

11. Before you were 18, did you ever buy a video game rated M (Mature) or AO (Adults Only)?

No, I have never purchased a video game rated $\mathrm{M}$ or $\mathrm{AO}$

No, I never tried to purchase video games rated

$\mathrm{M}$ or $\mathrm{AO}$ before I was 18

Yes, I did purchase videogames rated $\mathrm{M}$ or $\mathrm{AO}$ before I was 18

12. Has any video game vendor ever asked to see identification when you purchased a video game rated $\mathrm{M}$ or $\mathrm{AO}$ ?

Yes

No

I have never purchased a game

13. In the past five years, have you played any games such as Grand Theft Auto, Halo or any other violent video game?

Yes

No

14. Why do you play violent video games? (Mark all that apply.)

It is exciting 
It gives me a sense of “escape;” I don't think about anything while I am playing

It gives me a sense of power

It lets me test how quick my reflexes are

I am good at it

I feel a sense of community with players online from other parts of the country

I like being part of a team

I like winning

My friends like it, so I play with them

Other

15. On average, how violent are the video games you play?

$$
\begin{gathered}
\text { Hardly any } \\
\text { violence }
\end{gathered} \begin{gathered}
\text { Graphically and } \\
\text { disturbingly violent }
\end{gathered}
$$

$$
\text { O O O O O }
$$

16. At present, the only regulation on the sales of video games is the ratings system. Do you think regulations are necessary to prevent sales of $\mathrm{M}$ - or AO-rated games to minors?

Yes No _ I don't know

17. Do you think that video game content should be regulated by governmental legislation?

The government should regulate the content of video games

The government should not regulate the content of video games

18. In the past five years, have you purchased a violent video game rated $\mathrm{M}$ or AO for yourself?

Yes _ No

19. Would you continue to buy video games if the games were regulated to have no violent content?

Definitely ___ Maybe ___ I don't know 
Maybe not

Definitely not

20. There have been several court cases in which a teenager or young adult committed an act of violence and claimed he was acting out a scene in a violent video game. Should victims be able to sue the manufacturers of video games in these cases?

Yes, they should be allowed to sue to recover damages

No, they should not be allowed to sue to recover damages

I'm not sure; there are valid arguments on both sides

21. To what extent are violent video games responsible for an increase in violent behavior in real life?

There has not been a significant increase in violent behavior in real life

Not at all

To a small extent

A moderate extent

To a great extent

Almost all violence in real life is instigated by video games

Thank you for giving your opinions about video games above. Now we would like to ask for some demographic information in a few questions below:

22. Age: $18-19$

20-21

$22-24$

$25-30$

$31+$

23. Gender: Male

Female

24. Highest level of education: Attended High School

High School

Diploma

Attended College

2 Year College Degree

4 Year College Degree

Graduate Degree

25. In November 2008, I voted for

Barack Obama

John McCain

Other

Did not vote 
26. My religious beliefs could best be described as

Protestant
Friend (Quaker)
Catholic
_ Jewish
Hindu
Buddhist
Atheist
Agnostic
Other

27. My yearly income is (if you are still in college, please indicate your parents' income):

$\$ 0-9,999$

$\$ 10,000-29,999$

$\$ 30,000-49,999$

$\$ 50,000-69,999$

$\$ 70,000-89,999$

$\$ 90,000-109,999$

$\$ 110,000$ or above

28. If you have any additional comments about video games and violence, please put them here. 


\title{
Appendix B
}

\author{
HUMAN SUBJECTS PROTOCOL \\ University of Delaware
}

Protocol Title: Adult Perceptions of Violence in Video Games and Game Play

Principal Investigator

Name: Helen Wolf

Contact Phone Number: 410-215-3628

Email Address: hkwolf@udel.edu

Advisor (if student PI):

Name: Juliet Dee

Contact Phone Number: 302-762-2652

Email Address: juliedee@udel.edu

Other Investigators:

Type of Review:

$$
\text { Exempt }
$$

Expedited

Full board

Exemption Category:

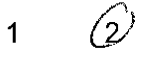

Minimal Risk:

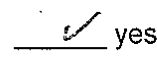

3

4

6

Submission Date: July 2, 2009

\begin{tabular}{|c|c|}
\hline 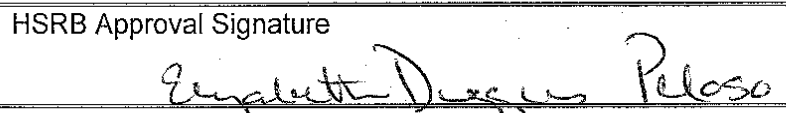 & $\begin{array}{l}\text { Approval Date } \\
716 / 09\end{array}$ \\
\hline $\begin{array}{l}\text { HS Number } \\
\qquad x M P 451\end{array}$ & $\begin{array}{l}\text { Approval Next Expires } \\
n / c_{L}\end{array}$ \\
\hline
\end{tabular}

Investigator Assurance:

By submitting this protocol, I acknowledge that this project will be conducted in strict accordance with the procedures described. I will not make any modifications to this protocol without prior approval by the HSRB. Should any unanticipated problems involving risk to subjects, including breaches of guaranteed confidentiality occur during this project, I will report such events to the Chair, Human Subjects Review Board immediately.

Signature of Investigator: Helen Wolf

Date: $7 / 2 / 09$ 


\section{Appendix C}

Table A1 Hours per week cross-tabulated with reported reaction time.

\begin{tabular}{|c|c|c|c|c|c|}
\hline & & & \multicolumn{2}{|c|}{ Reaction Time } & \multirow[b]{2}{*}{ Total } \\
\hline & & & Not at all & Yes & \\
\hline \multirow{4}{*}{$\begin{array}{l}\text { Hours per } \\
\text { week }\end{array}$} & $0-5$ & Count & 120 & 137 & 257 \\
\hline & & $\%$ of Total & $37.3 \%$ & $42.5 \%$ & $79.8 \%$ \\
\hline & $6+$ & Count & 3 & 62 & 65 \\
\hline & & $\%$ of Total & $.9 \%$ & $19.3 \%$ & $20.2 \%$ \\
\hline \multirow[t]{2}{*}{ Total } & & Count & 123 & 199 & 322 \\
\hline & & $\%$ of Total & $38.2 \%$ & $61.8 \%$ & $100.0 \%$ \\
\hline
\end{tabular}


Table A2 Evaluation of hours per week and reaction time improvement.

\begin{tabular}{|l|l|l|l|l|l|}
\hline & Value & Df & $\begin{array}{l}\text { Asymp. Sig. } \\
\text { (2-sided) }\end{array}$ & $\begin{array}{l}\text { Exact Sig. } \\
\text { (2-sided) }\end{array}$ & $\begin{array}{l}\text { Exact Sig. } \\
\text { (1-sided) }\end{array}$ \\
\hline Pearson Chi-Square & 38.908 & 1 & .000 & & \\
Continuity Correction & 37.146 & 1 & .000 & & \\
Likelihood Ratio & 48.812 & 1 & .000 & .000 & .000 \\
Fisher's Exact Test & 38.787 & 1 & .000 & & \\
Linear-by-Linear Association & 322 & & & & \\
N of Valid Cases & $\mathrm{p}<0.01$
\end{tabular}

Table A3 Hours per week cross-tabulated with improvement in social network.

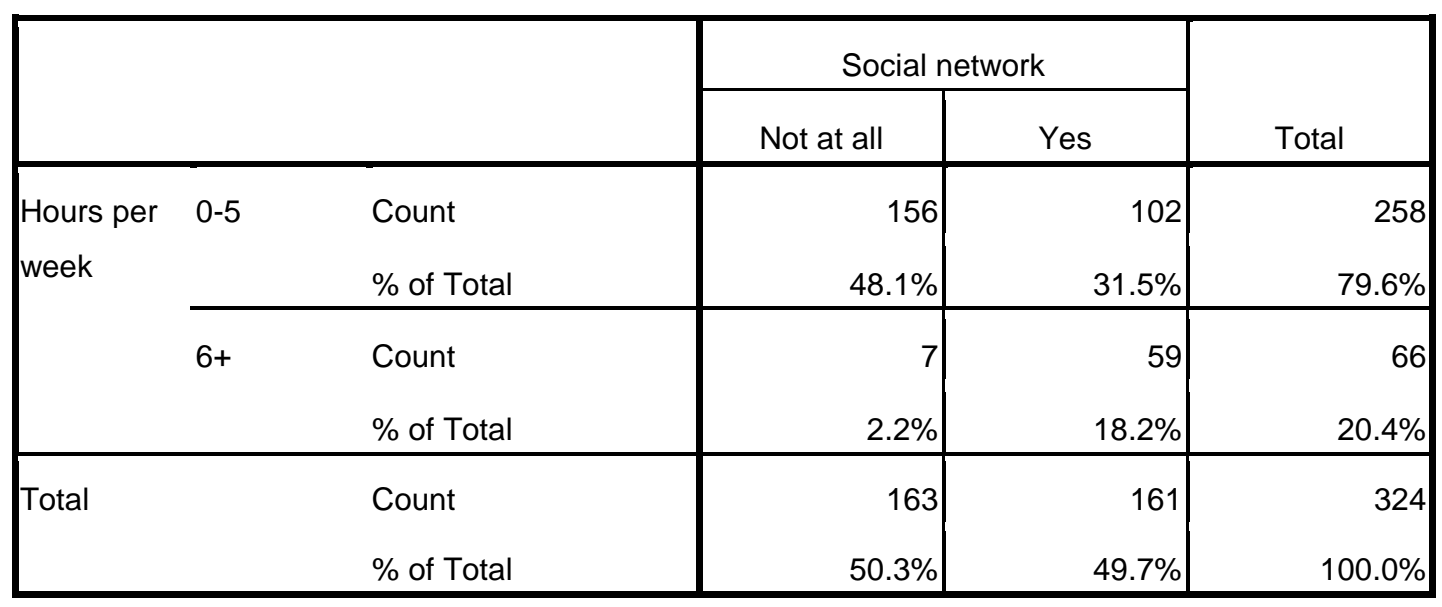


Table A4 Evaluation of hours per week and social network expansion.

\begin{tabular}{|c|c|c|c|c|c|}
\hline & Value & $d f$ & $\begin{array}{c}\text { Asymp. Sig. (2- } \\
\text { sided) }\end{array}$ & $\begin{array}{l}\text { Exact Sig. (2- } \\
\text { sided) }\end{array}$ & $\begin{array}{l}\text { Exact Sig. (1- } \\
\text { sided) }\end{array}$ \\
\hline Pearson Chi-Square & 52.262 & 1 & .000 & \multirow{7}{*}{.000} & \multirow{7}{*}{.000} \\
\hline Continuity Correction & 50.286 & 1 & .000 & & \\
\hline Likelihood Ratio & 58.227 & 1 & .000 & & \\
\hline Fisher's Exact Test & & & & & \\
\hline Linear-by-Linear & 52.100 & 1 & .000 & & \\
\hline Association & & & & & \\
\hline$N$ of Valid Cases & 324 & & & & \\
\hline
\end{tabular}

Table A5 Evaluation of hours played per week and whether the ratings system is perceived as necessary.

\begin{tabular}{|c|c|c|c|c|c|}
\hline & Value & df & $\begin{array}{c}\text { Asymp. Sig. (2- } \\
\text { sided) }\end{array}$ & $\begin{array}{l}\text { Exact Sig. (2- } \\
\text { sided) }\end{array}$ & $\begin{array}{c}\text { Exact Sig. (1- } \\
\text { sided) }\end{array}$ \\
\hline Pearson Chi-Square & .041 & 1 & .840 & & \\
\hline Continuity Correction & .002 & 1 & .961 & & \\
\hline Likelihood Ratio & .041 & 1 & .840 & & \\
\hline Fisher's Exact Test & & & & .880 & 485 \\
\hline Linear-by-Linear & .040 & 1 & .841 & & \\
\hline $\mathrm{N}$ of Valid Cases & 314 & & & & \\
\hline
\end{tabular}

$\mathrm{p}>0.01$ 
Table A6 Hours per week and whether the ratings system is perceived as necessary.

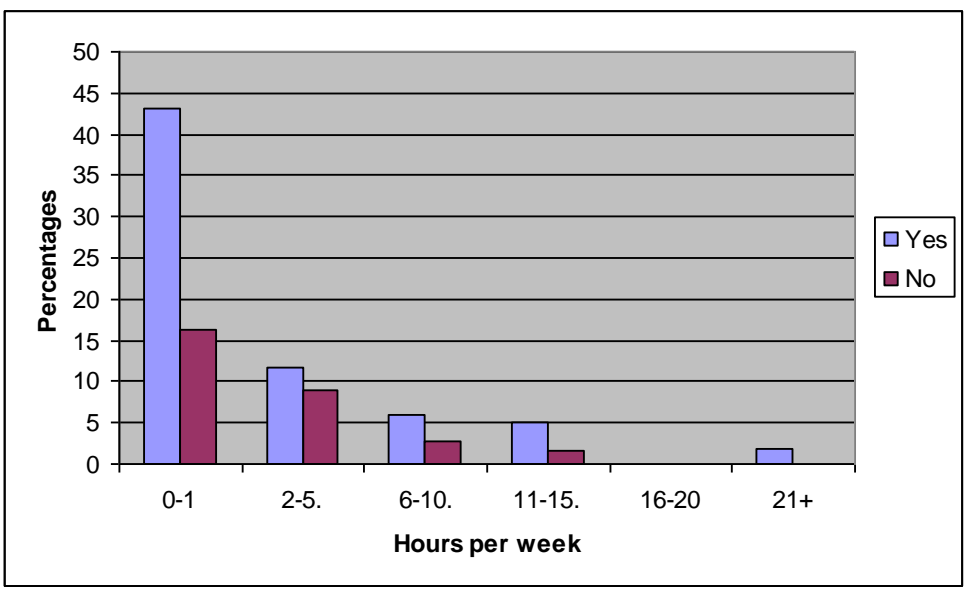

Table A7 Hours per week cross-tabulated with perception of the need for government regulations.

\begin{tabular}{|lll|l|l|l|}
\hline & & \multicolumn{2}{|l|}{ Congressional regulations? } & \multirow{2}{*}{ Total } \\
\cline { 3 - 5 } & & Yes & No & 250 \\
\hline $\begin{array}{l}\text { Hours } \\
\text { per } \\
\text { week }\end{array}$ & $0-5$ & Count & 65 & 185 & $79.6 \%$ \\
\cline { 2 - 5 } & \% of Total & Count & $20.7 \%$ & $58.9 \%$ & 64 \\
& \% of Total & 6 & 58 & $20.4 \%$ \\
\hline Total & Count & $1.9 \%$ & $18.5 \%$ & 314 \\
& \% of Total & 71 & 243 & $100.0 \%$ \\
\hline
\end{tabular}

Table A8 Evaluation of hours per week and a perception of government regulation

Chi-Square Tests

\begin{tabular}{|l|l|l|l|}
\hline & Value & Df & Asymp. Sig. (2-sided) \\
\hline Pearson Chi-Square & 20.789 & 5 & .001 \\
Likelihood Ratio & 25.138 & 5 & .000 \\
Linear-by-Linear Association & 13.161 & 1 & .000 \\
$\mathrm{~N}$ of Valid Cases & 313 & & \\
\hline $\mathrm{p}<0.01$ &
\end{tabular}


Table A9 Hours per week cross-tabulated with attitudes about whether victims of imitated violence should be able to sue manufacturers for damages.

\begin{tabular}{|c|c|c|c|c|c|c|}
\hline & & & \multicolumn{3}{|c|}{ Judicial interference } & \multirow[b]{2}{*}{ Total } \\
\hline & & & Yes & No & I'm not sure & \\
\hline \multirow{6}{*}{$\begin{array}{l}\text { Hours } \\
\text { per } \\
\text { week }\end{array}$} & $0-1$ & Count & 10 & 119 & 57 & 186 \\
\hline & & $\%$ of Total & $3.2 \%$ & $37.8 \%$ & $18.1 \%$ & $59.0 \%$ \\
\hline & $2-5$ & Count & 3 & 52 & 10 & 65 \\
\hline & & $\%$ of Total & $1.0 \%$ & $16.5 \%$ & $3.2 \%$ & $20.6 \%$ \\
\hline & $6+$ & Count & 1 & 57 & 6 & 64 \\
\hline & & $\%$ of Total & $.3 \%$ & $18.1 \%$ & $1.9 \%$ & $20.3 \%$ \\
\hline \multirow[t]{2}{*}{ Total } & & Count & 14 & 228 & 73 & 315 \\
\hline & & $\%$ of Total & $4.4 \%$ & $72.4 \%$ & $23.2 \%$ & $100.0 \%$ \\
\hline
\end{tabular}

Table A10 Graph of hours per week playing video games and whether victims of imitated violence should be able to sue manufacturers.

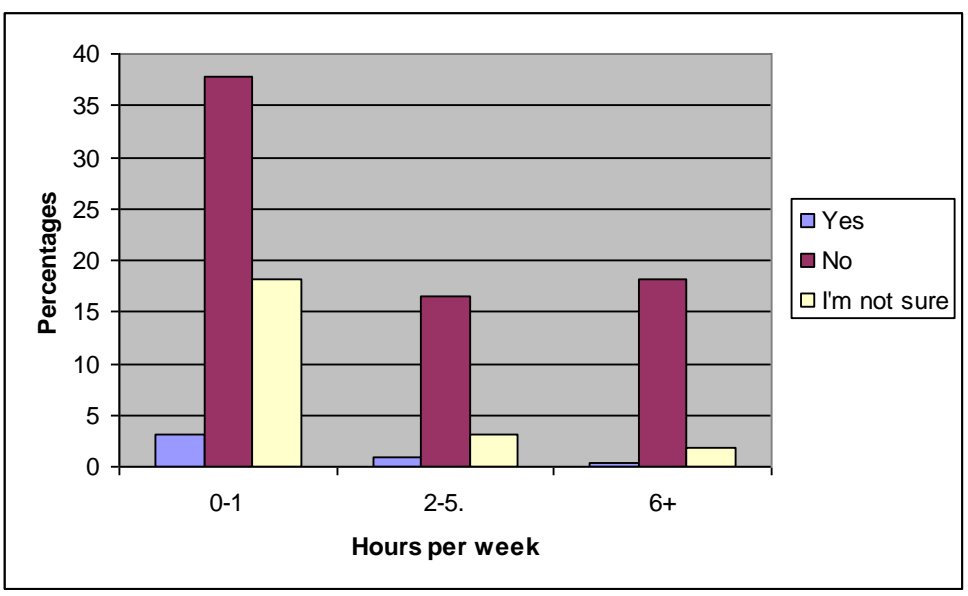


Table A11 Evaluation of effects on real life violence and a perception of governmental regulation.

\begin{tabular}{|c|c|c|c|c|c|}
\hline & Value & $d f$ & $\begin{array}{l}\text { Asymp. Sig. (2- } \\
\text { sided) }\end{array}$ & $\begin{array}{l}\text { Exact Sig. (2- } \\
\text { sided) }\end{array}$ & $\begin{array}{l}\text { Exact Sig. (1- } \\
\text { sided) }\end{array}$ \\
\hline Pearson Chi-Square & 3.915 & 1 & .048 & & \\
\hline Continuity Correction & 3.251 & 1 & .071 & & \\
\hline Likelihood Ratio & 4.024 & 1 & .045 & & \\
\hline Fisher's Exact Test & & & & .055 & .035 \\
\hline $\begin{array}{l}\text { Linear-by-Linear } \\
\text { Association }\end{array}$ & & 1 & .049 & & \\
\hline $\mathrm{N}$ of Valid Cases & 154 & & & & \\
\hline
\end{tabular}

$\mathrm{p}<0.05$

Table A12 Effects on real life violence and a perception of government regulations.

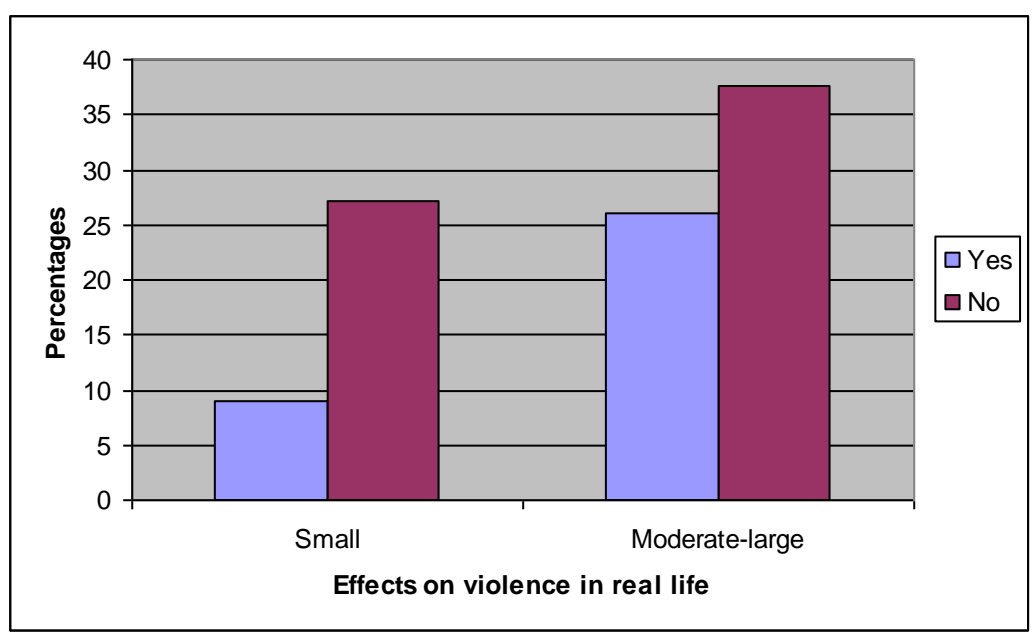


Table A13 Effects on real life violence cross-tabulated with whether victims of imitated violence can sue manufacturers.

\begin{tabular}{|c|c|c|c|c|c|c|}
\hline & & & \multicolumn{3}{|c|}{ Judicial Interference } & \multirow[b]{2}{*}{ Total } \\
\hline & & & Yes & No & I'm not sure & \\
\hline \multirow{4}{*}{$\begin{array}{l}\text { How } \\
\text { Responsible }\end{array}$} & \multirow[t]{2}{*}{ Small +1} & Count & 1 & 41 & 15 & 57 \\
\hline & & $\%$ of Total & $.6 \%$ & $26.1 \%$ & $9.6 \%$ & $36.3 \%$ \\
\hline & \multirow{2}{*}{$\begin{array}{l}\text { Moderate- } \\
\text { large }\end{array}$} & Count & 10 & 53 & 37 & 100 \\
\hline & & $\%$ of Total & $6.4 \%$ & $33.8 \%$ & $23.6 \%$ & $63.7 \%$ \\
\hline \multirow[t]{2}{*}{ Total } & & Count & 11 & 94 & 52 & 157 \\
\hline & & $\%$ of Total & $7.0 \%$ & $59.9 \%$ & $33.1 \%$ & $100.0 \%$ \\
\hline
\end{tabular}

Table A14 Evaluation of effects on real life violence and whether victims of imitated violence can sue manufacturers.

\begin{tabular}{|l|l|l|l|}
\hline & Value & df & Asymp. Sig. (2-sided) \\
\hline Pearson Chi-Square & 6.947 & 2 & .031 \\
Likelihood Ratio & 7.762 & 2 & .021 \\
Linear-by-Linear Association & .064 & 1 & .800 \\
N of Valid Cases & 157 & & \\
\hline
\end{tabular}

$p<0.05$

Table A15 Gender support cross tabulated with whether ratings are necessary.

\begin{tabular}{|ll|l|l|l|}
\hline \multirow{4}{*}{} & \multicolumn{2}{|l|}{ Gender: } & \multirow{2}{*}{} \\
\cline { 2 - 4 } & Male & Female & Total \\
\hline Agreement with the ratings & Yes & 87 & 151 & 238 \\
system. & No & 56 & 44 & 100 \\
Total & & 143 & 195 & 338 \\
\hline
\end{tabular}


Table A16 Evaluation of gender support and whether ratings are necessary.

Chi-Square Tests

\begin{tabular}{|l|l|l|l|l|l|}
\hline & Value & df & $\begin{array}{l}\text { Asymp. Sig. (2- } \\
\text { sided) }\end{array}$ & $\begin{array}{l}\text { Exact Sig. (2- } \\
\text { sided) }\end{array}$ & $\begin{array}{l}\text { Exact Sig. (1- } \\
\text { sided) }\end{array}$ \\
\hline Pearson Chi-Square & 10.908 & 1 & .001 & & \\
Continuity Correction & 10.126 & 1 & .001 & & \\
Likelihood Ratio & 10.835 & 1 & .001 & .001 & .001 \\
$\begin{array}{l}\text { Fisher's Exact Test } \\
\text { Linear-by-Linear }\end{array}$ & 10.876 & 1 & .001 & & \\
Association & 338 & & & & \\
$\mathrm{~N}$ of Valid Cases & $\mathrm{p}<0.01$ & & & & \\
\hline
\end{tabular}

Table A17 Cross-tabulation of gender and victim ability to sue.

\begin{tabular}{|ll|l|l|l|}
\hline \multicolumn{4}{|c|}{} & \multicolumn{2}{|l|}{ Gender: } & \\
\cline { 3 - 4 } & & Male & Female & Total \\
\hline Judicial support for victims? & Yes & 3 & 11 & 14 \\
& No & 124 & 119 & 243 \\
& I'm not sure & 16 & 66 & 82 \\
Total & & 143 & 196 & 339 \\
\hline
\end{tabular}

Table A18 Chi-square test of gender and victim ability to sue.

\begin{tabular}{|c|c|c|c|c|c|}
\hline & Value & df & $\begin{array}{c}\text { Asymp. Sig. (2- } \\
\text { sided) }\end{array}$ & $\begin{array}{l}\text { Exact Sig. (2- } \\
\text { sided) }\end{array}$ & $\begin{array}{l}\text { Exact Sig. (1- } \\
\text { sided) }\end{array}$ \\
\hline Pearson Chi-Square & 27.609 & 1 & .000 & \multirow{7}{*}{.000} & \multirow{7}{*}{.000} \\
\hline Continuity Correction & 26.270 & 1 & .000 & & \\
\hline Likelihood Ratio & 29.979 & 1 & .000 & & \\
\hline Fisher's Exact Test & & & & & \\
\hline Linear-by-Linear & 27.527 & 1 & .000 & & \\
\hline Association & & & & & \\
\hline $\mathrm{N}$ of Valid Cases & 337 & & & & \\
\hline
\end{tabular}

$\mathrm{p}<0.001$ 